\title{
Impacts of the Sahel-Sahara Interface Reforestation on West African Climate: Intraseasonal Variability and Extreme Precipitation Events
}

\author{
Ibrahima Diba, Moctar Camara, and Alioune Badara Sarr \\ Laboratoire d'Océanographie, des Sciences de l'Environnement et du Climat (LOSEC), UFR des Sciences et Technologies, \\ Université Assane SECK de Ziguinchor, Ziguinchor, Senegal \\ Correspondence should be addressed to Moctar Camara; moctarlsn@yahoo.fr
}

Received 17 April 2016; Revised 30 August 2016; Accepted 22 September 2016

Academic Editor: Yu Zhang

Copyright (C) 2016 Ibrahima Diba et al. This is an open access article distributed under the Creative Commons Attribution License, which permits unrestricted use, distribution, and reproduction in any medium, provided the original work is properly cited.

\begin{abstract}
This study aims to evaluate the impacts of the Sahel-Sahara interface reforestation on spatiotemporal variability of the summer rainfall and extreme precipitation events over West Africa using the RegCM4 model. The land surface scheme of RegCM4 was modified to incorporate an East-West reforested zone $\left(15^{\circ} \mathrm{N}\right.$ and $\left.20^{\circ} \mathrm{N}\right)$. Two runs were performed using the standard version of RegCM4 and the modified one of the same model taking into account the incorporated forest. The reforestation significantly modifies rainfall signal over West Africa by increasing it over the reforested zone and the Fouta Jallon highlands (FJH). This rainfall increase is associated with a strengthening of the atmospheric moisture over the reforested area. This atmospheric moisture content increase associated with the wind dynamic may explain the spatiotemporal change of the rainfall and extreme precipitation events. The analysis of the impacts of the reforestation on some rainfall indices shows an increase of the 90th, 95th, and 99th percentiles over the reforested zone and off the FJH. This reforestation also causes an increase of the maximum length of the consecutive wet days over and off FJH and a decrease of the maximum length of the consecutive dry days over the northern Sahel and the reforested zone.
\end{abstract}

\section{Introduction}

West Africa (especially its semiarid region called the Sahel) has experienced a large rainfall variability during these last decades [1]. This variability often translates into severe drought and flooding events which negatively impact water resources availability and food security $[2,3]$. The variability of West African climate is marked by a strong dry episode, punctuated by years of severe drought [4] which has led many scientists to study the possible causes [1,5-7]. This drought had a severe impact on the economy of affected countries, causing humanitarian crisis as well as important migration of the population or deaths due to famine. The search of the key factors or mechanisms that may explain this drought has progressed in several parallel directions. One mechanism proposed by some authors [8-10] highlights the importance of the atmospheric response on sea surface temperature variations as a major cause of this drought. The other mechanism highlights the role of the feedback between atmospheric circulation and land surface processes [11-14]. Charney [13], in a pioneering work, proposed a positive feedback between rainfall and albedo via local vegetation modification and land surface processes to explain the drought that occurred in the Sahel. Konaré et al. [15] and Camara et al. [16] have studied the impacts of Saharan dust emissions on West African climate. Their results show that the increase in dust emissions has also contributed to the drought that occurred in the Sahel region. Furthermore, some authors suggest that this drought was caused by the possible effect of global climate change $[17,18]$ or the variability of African easterly waves [19] and wind dynamics [11]. However, the period after 1993 seems to be a turning point for the Sahel with the succession of very wet years and very dry years [20].

These authors found that the drought is still going on in the western Sahel while the eastern part of that region is experiencing a gradual recovery (return to wet conditions). However, this general tendency is sometimes punctuated by the occurrence of extreme hydroclimatic events such 
as flooding and strong dry spells which have dramatic socioeconomic impacts on West African countries.

Moreover, environmental modifications related to the population growth in this region have resulted in strong changes of the natural land cover. These changes vary from the removal of vegetation in the grassland region of the north (desertification) to the removal of forest in the south (deforestation). Zheng and Eltahir [21] performed some deforestation and desertification experiments using a climate model. They found that the West African monsoon circulation and rainfall variability are more sensitive to deforestation than to desertification. Furthermore, Abiodun et al. [22] investigate the potential impacts of land cover changes on the summer West African climate and determined some mechanisms through which these land cover changes modify the West African monsoon circulation. Xue et al. [23] showed that vegetation processes are important for WAM evolution affecting both the intensity and spatial extent of precipitation and the associated circulation. Over the West African regions, extensive studies of daily rainfall characteristics and extreme events have been limited because the spatial distribution of rain gauges is not sufficient enough to describe the local, regional, and large-scale hydrological phenomena $[24,25]$. Nevertheless, considerable efforts have been devoted to research on extreme precipitation events over West Africa [3, 26-29]. Globally, their results indicate the existence of large uncertainties related to the simulation of daily rainfall characteristics by the regional climate models (RCMs). However, none of these studies have attempted to investigate the impacts of the reforestation at the SahelSahara interface on daily extreme precipitation events. This work aims at evaluating the impacts of the Sahel-Sahara interface reforestation on intraseasonal variability of precipitation as well as on the spatial distribution of extreme precipitation events over West Africa during the peak of the monsoon season (June to September) using the Abdu Salam ICTP regional climate model RegCM4. This model is often used to downscale the output of general circulation models or the reanalysis aiming at better describing the small scale physical processes and complex topography or land use heterogeneity. Numerous studies show the ability of this model (due to its high spatial resolution) to simulate the variability of West African monsoon [26, 30]. This work also provides an opportunity to assess the potential impacts of the Great Green Wall (GGW) project on West African monsoon from the modeling point of view. This GGW project is an African initiative aiming to green a strip of land extending from Dakar (Senegal) to Djibouti in order to fight against the desertification. Model description, experimental setup, and the data used are presented in the next section followed by the results and the discussion.

\section{Model Description, Experimental Setup, and Data Used}

2.1. Model Description and Experimental Setup. In this study, we used the standard version of the regional climate model (RCM) RegCM4 developed at the Abdu Salam International Centre for Theoretical Physics (ICTP, Trieste, Italy) as

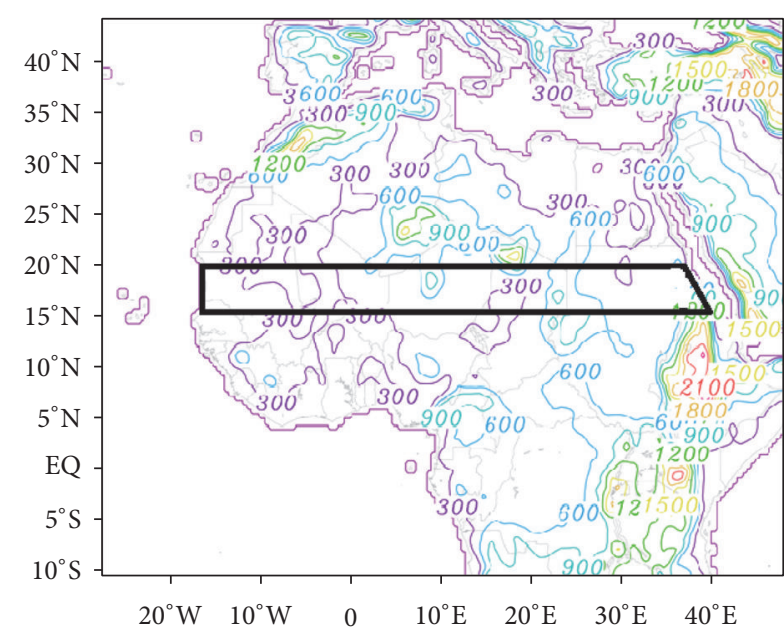

FIgURE 1: Topography of the simulation domain (West Africa) and the reforested zone (between $15^{\circ} \mathrm{N}$ and $20^{\circ} \mathrm{N}$ ).

described by Giorgi et al. [31]. Land surface processes are simulated using the Biosphere Atmosphere Transfer Scheme 1E (BATS1E) described in Dickinson et al. [32]. Holtslag et al. [33] model is used for the parameterization of the planetary boundary layer. The large-scale rain is parameterized with the subgrid explicit moisture and cloud scheme (SUBEX) developed by Pal et al. [34]. The convection schemes used are those of Grell [35] with the closure of Fritsch and Chappell [36] for the main land and Emanuel [37] for the ocean. Horizontal and vertical resolutions are, respectively, $50 \mathrm{~km}$ and 18 vertical levels.

The simulation domain is lying between latitudes $10^{\circ} \mathrm{S}-$ $47^{\circ} \mathrm{N}$ and longitudes $27^{\circ} \mathrm{W}-47^{\circ} \mathrm{E}$ (Figure 1). The domain is large enough to properly simulate the processes that govern rainfall variability over West Africa and to minimize inconsistencies between boundary conditions and the model. Two experiments (model runs) are performed using two different land cover patterns shown in Figure 2. We extend the land cover changes from the east to the west of the simulation domain (Figure 2) to have zonally land cover patterns between latitudes $15^{\circ} \mathrm{N}$ and $20^{\circ} \mathrm{N}$. Names of the different types of land cover used in this study are shown in Table 1. Each type of land cover is associated with a value to be found on the legend of Figure 2. In the first experiment (Figure 2(a)), which is the control (CTR) for this study, we use the default land cover (vegetation) of West Africa provided by the standard version of RegCM4 model. The second experiment (named RegCM4_REFORESTATION) is identical to the first with the exception that the land cover over the region between $15^{\circ} \mathrm{N}$ and $20^{\circ} \mathrm{N}$ which is a combination of grass $\left(15^{\circ} \mathrm{N}-16^{\circ} \mathrm{N}\right)$, semidesert $\left(16^{\circ} \mathrm{N}-18^{\circ} \mathrm{N}\right)$, and desert $\left(18^{\circ} \mathrm{N}-20^{\circ} \mathrm{N}\right)$ is changed to forest (Figure 2(b)). The model has been integrated from November 2002 to the end of December 2009. The first two months (November and December 2002) were discarded for model spin-up. The impacts of the reforestation were studied using ten (10) hydroclimatic indices recommended by World Meteorology Organization [38] summarized in Table 2. These climate indices are known for their great impacts on the water resources availability and agricultural productivity. 


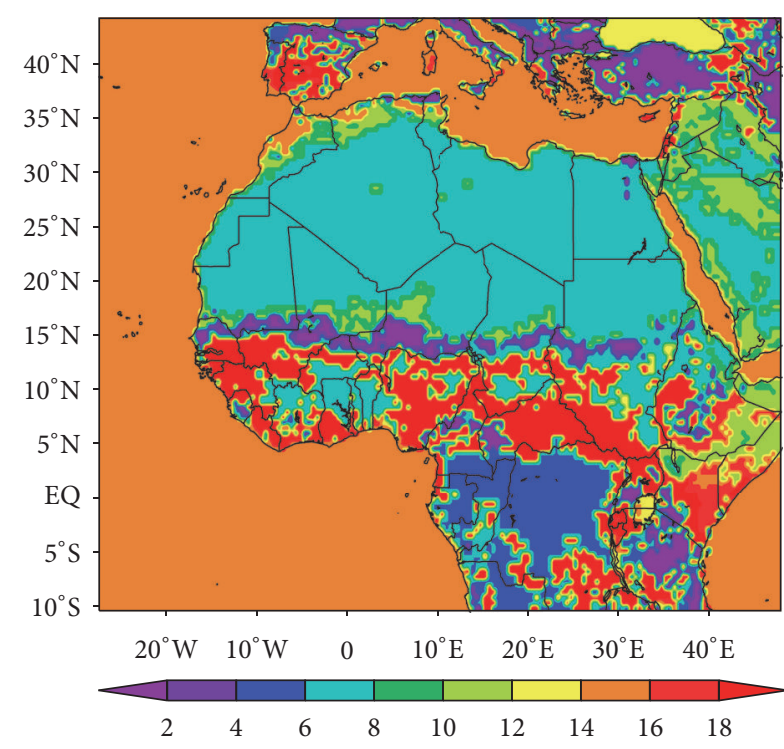

(a) $\mathrm{RegCM} 4$

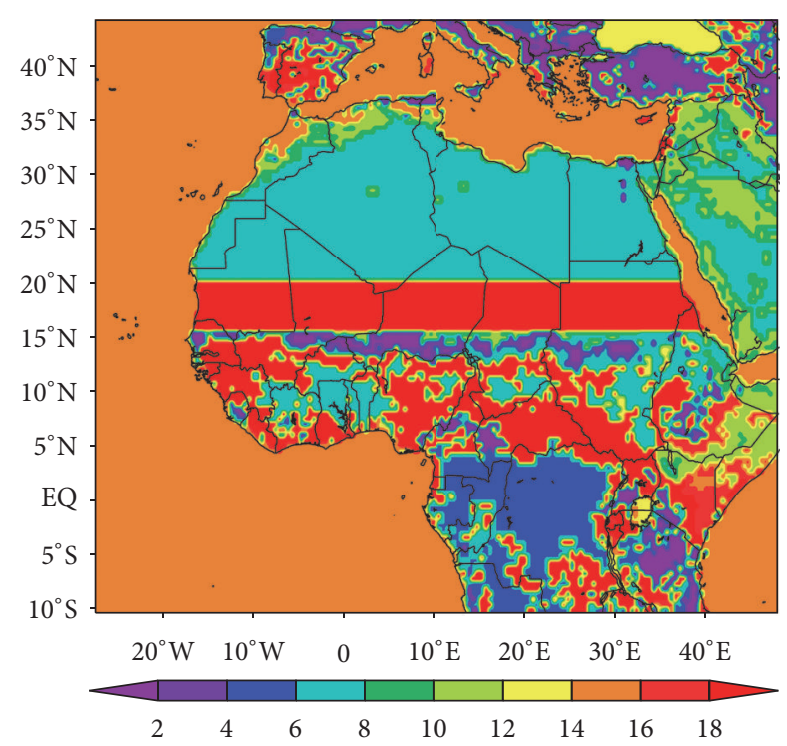

(b) RegCM4_REFORESTATION

FIGURE 2: Distribution of land cover types used in this study: (a) the standard version of RegCM4 model and (b) the reforested one RegCM4_REFORESTATION. The red rectangle indicates the reforested zone.

TABLE 1: Land cover types used in this study.

\begin{tabular}{|c|c|c|c|c|c|c|c|c|}
\hline$[0-2]$ & [2-4] & [4-6] & {$[6-8]$} & [8-10] & {$[10-12]$} & [12-14] & [14-16] & [16-18] \\
\hline Crop & Irrigated crop & Short grass & Desert & Semidesert & Tall grass & Inland water & Marsh or bog & Disturbed forest \\
\hline
\end{tabular}

NB: The values above indicate the type of land cover used in this study which can be found in the legend of Figure 2.

TABLe 2: Definition of climate indices.

\begin{tabular}{|c|c|}
\hline Indices & Definitions \\
\hline Number of wet days $(R>1 \mathrm{~mm})$ & Number of days with daily cumulative precipitation greater than $1 \mathrm{~mm}$ \\
\hline $\begin{array}{l}\text { Simple daily intensity index (SDII) } \\
\mathrm{mm} / \text { day }\end{array}$ & Precipitation intensity due to the wet days only \\
\hline Frequency of intense rainfall events $(R \geq 10 \mathrm{~mm})$ & $\begin{array}{l}\text { Number of days with daily precipitation greater than or equal to } \\
10 \mathrm{~mm}\end{array}$ \\
\hline Frequency of very intense rainfall events $(R \geq 20 \mathrm{~mm})$ & $\begin{array}{l}\text { Number of days with daily precipitation greater than or equal to } \\
20 \mathrm{~mm}\end{array}$ \\
\hline $\begin{array}{l}\text { Maximum 5-day precipitation (RX5day) } \\
\mathrm{mm} / \text { day }\end{array}$ & The maximum of 5-day precipitation accumulations \\
\hline $\begin{array}{l}\text { 90th percentile (wet days) } \\
\mathrm{mm} / \text { day }\end{array}$ & The value below which $90 \%$ of the data are found \\
\hline $\begin{array}{l}\text { 95th percentile (very wet days) } \\
\mathrm{mm} / \text { day }\end{array}$ & The value below which $95 \%$ of the data are found \\
\hline $\begin{array}{l}\text { 99th percentile (extremely wet days) } \\
\mathrm{mm} \text { /day }\end{array}$ & The value below which $99 \%$ of the data are found \\
\hline Maximum wet spell length (CWD) & $\begin{array}{l}\text { Maximum length of the consecutive wet days with daily rainfall } \\
\text { greater than } 1 \mathrm{~mm}\end{array}$ \\
\hline Maximum dry spell length (CDD) & $\begin{array}{l}\text { Maximum length of the consecutive dry days with daily rainfall below } \\
1 \mathrm{~mm}\end{array}$ \\
\hline
\end{tabular}

2.2. Data. The observed precipitation data of the Global Precipitation Climatology Project (GPCP) with a spatial resolution of $2.5^{\circ} \times 2.5^{\circ}$ [39] are used to validate the model. GPCP rainfall data are a combination of in situ measurements (rain gauges) and satellite rainfall products. These observed data are extensively used by the scientific community. Many studies show that the GPCP climatology can better represent the spatiotemporal variability of the West African rainfall and that is the reason why we chose it as the reference for the observation data $[40,41]$. Model simulations are initialized 


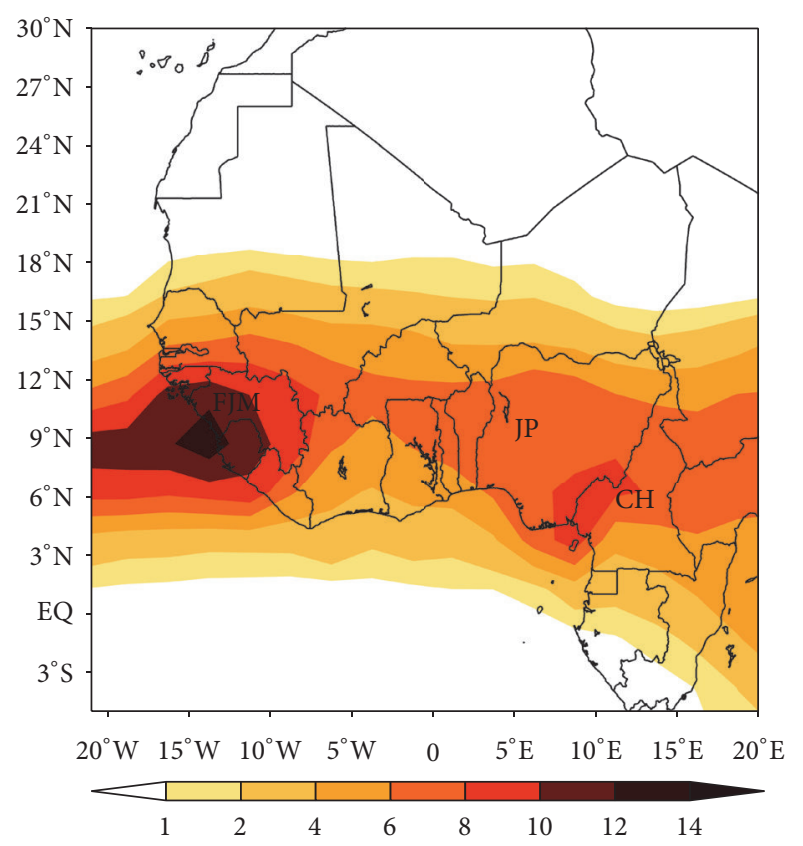

(a) JJAS GPCP

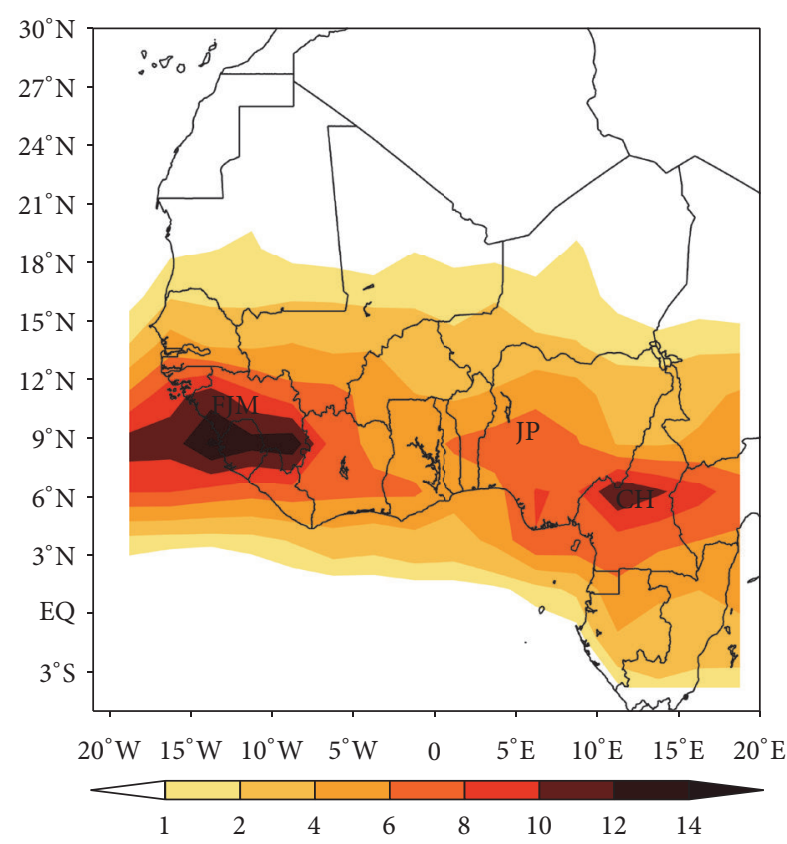

(b) JJAS RegCM4

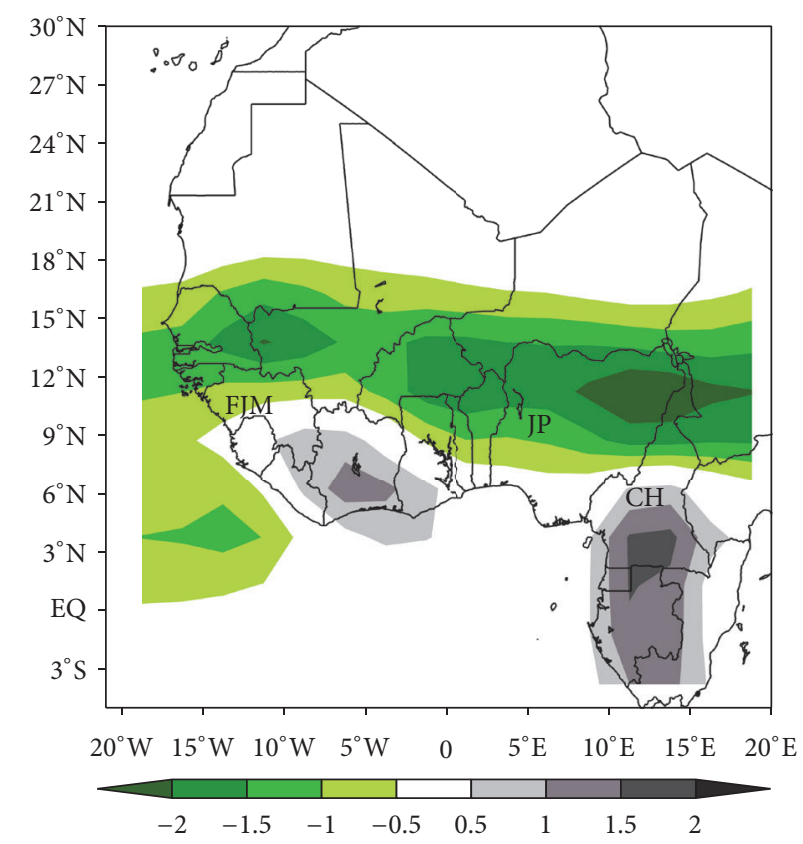

(c) JJAS (RegCM4 - GPCP)

FIGURE 3: Mean summer rainfall (mm/day) averaged from 2003 to 2009 over West Africa: (a) GPCP climatology, (b) RegCM4, and (c) RegCM4 - GPCP.

and driven by the ERA-Interim reanalysis (spatial resolution of $1.5^{\circ} \times 1.5^{\circ},[42,43]$ ).

A reanalysis data is the result of the combination of the outputs of a numerical weather model with all available observation data. In areas where the observation density is relatively low, the representation of the physical processes is largely dependent on the model processes. The meteorological reanalyses are currently the best way to describe the state of the atmosphere especially in areas where the in situ observation data are insufficient such as West Africa. The
ERA-Interim reanalyses are available from 1979 to the present time and have been used previously for various studies [30, 44-46] because of their good ability to reproduce the main components of the West African monsoon system [47, 48].

\section{Results and Discussions}

3.1. Intraseasonal Rainfall Variability. We first validated the standard version of the RegCM4 model before studying the impacts of reforestation on West Africa by comparing the 


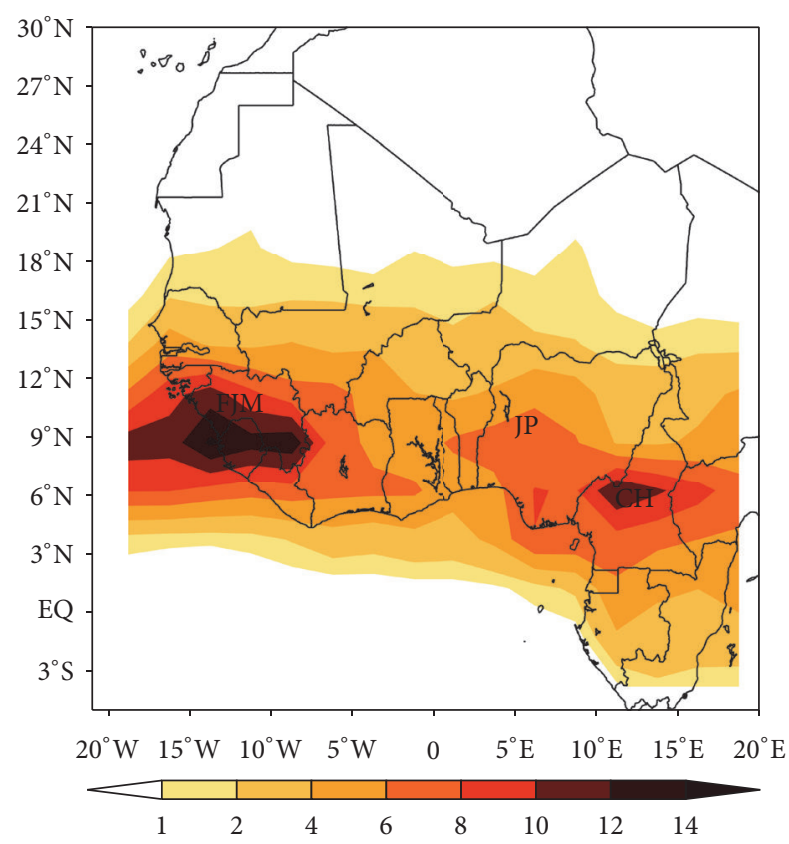

(a) JJAS RegCM4

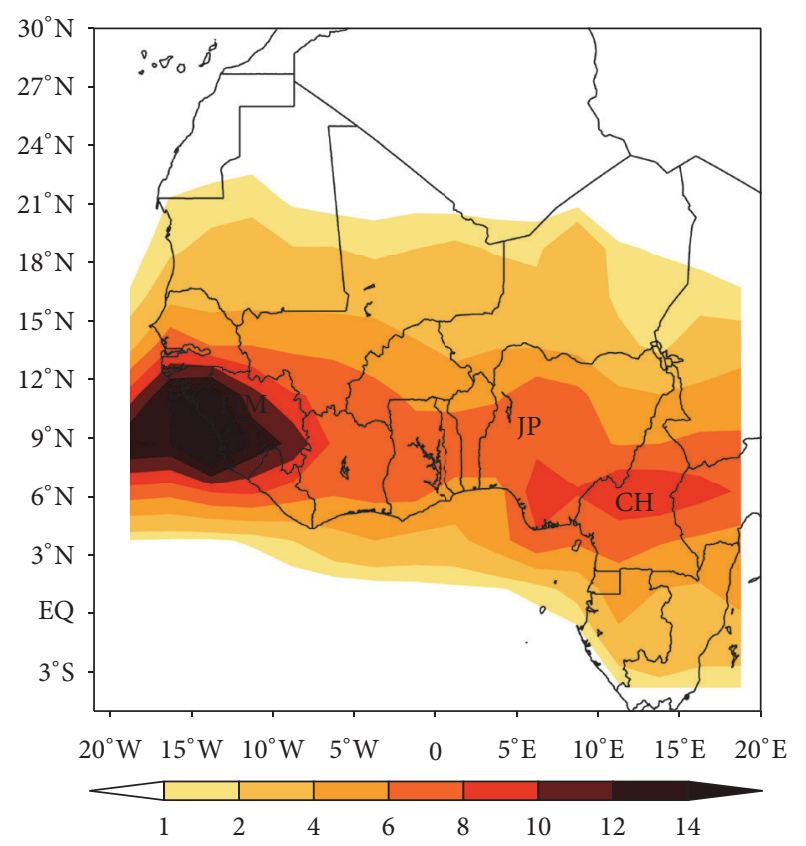

(b) JJAS RegCM4_REFORESTATION

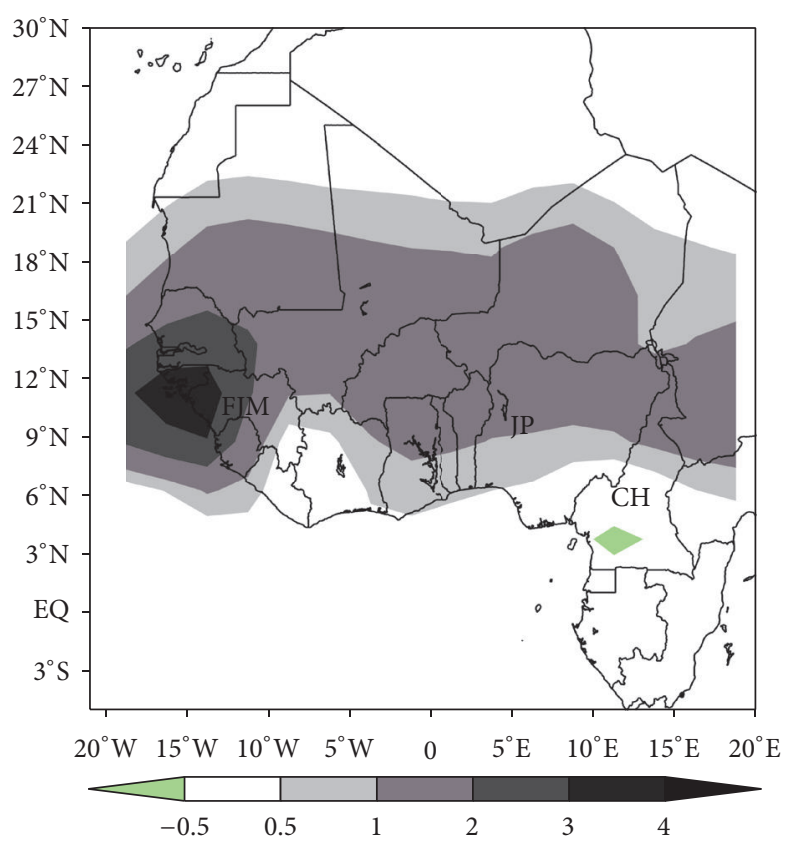

(c) JJAS (RegCM4_REFORESTATION - RegCM4)

FiguRE 4: Mean summer rainfall (mm/day) averaged from 2003 to 2009 over West Africa: (a) RegCM4, (b) RegCM4_REFORESTATION, and (c) difference between RegCM4_REFORESTATION and RegCM4.

summer rainfall simulated by the model with the GPCP observation data.

Figure 3 represents the mean summer rainfall (June to September from 2003 to 2009) for the GPCP climatology and the standard version of RegCM4 model and their difference. GPCP climatology exhibits a zonal distribution with precipitation decreasing from the South to the North and maxima located over orographic regions: Fouta Jallon mountains (FJM), Jos Plateau (JP), and Cameroon Highlands $(\mathrm{CH})$. The standard version of RegCM4 reproduces the zonal structure of rainfall as well as the maxima. The difference between the standard version of RegCM4 and the GPCP climatology ranges between $-2 \mathrm{~mm}$ /day over the Sahel region and $2 \mathrm{~mm} /$ day over the Guinean coast $\left(3^{\circ} \mathrm{N}-7^{\circ} \mathrm{N}\right)$. This low bias shows the ability of the RegCM4 model to simulate West African climate. The next step is to evaluate 


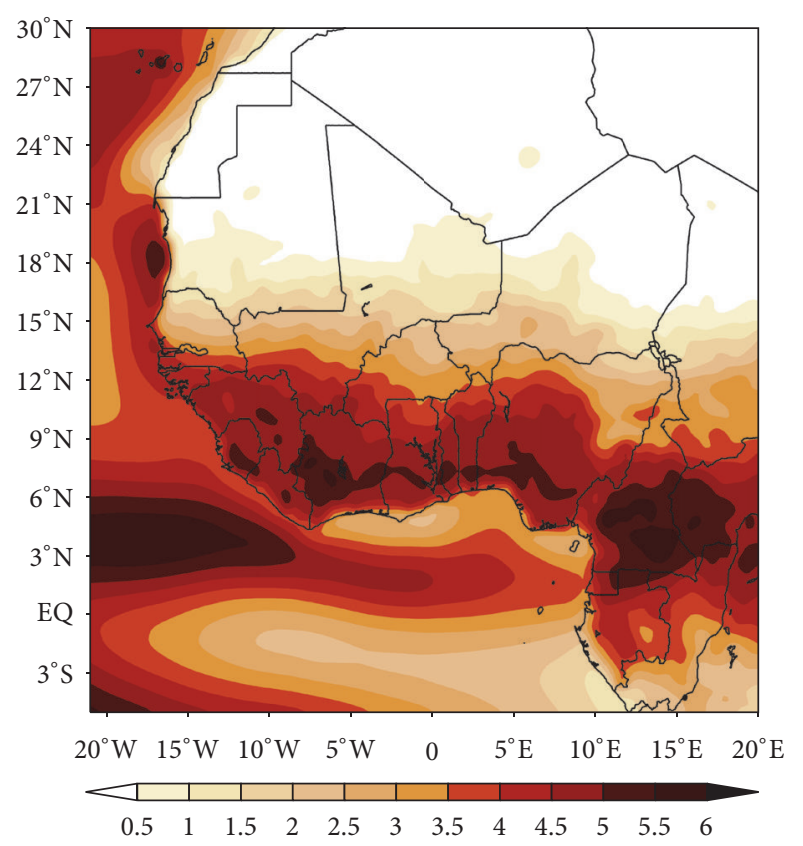

(a) JJAS RegCM4

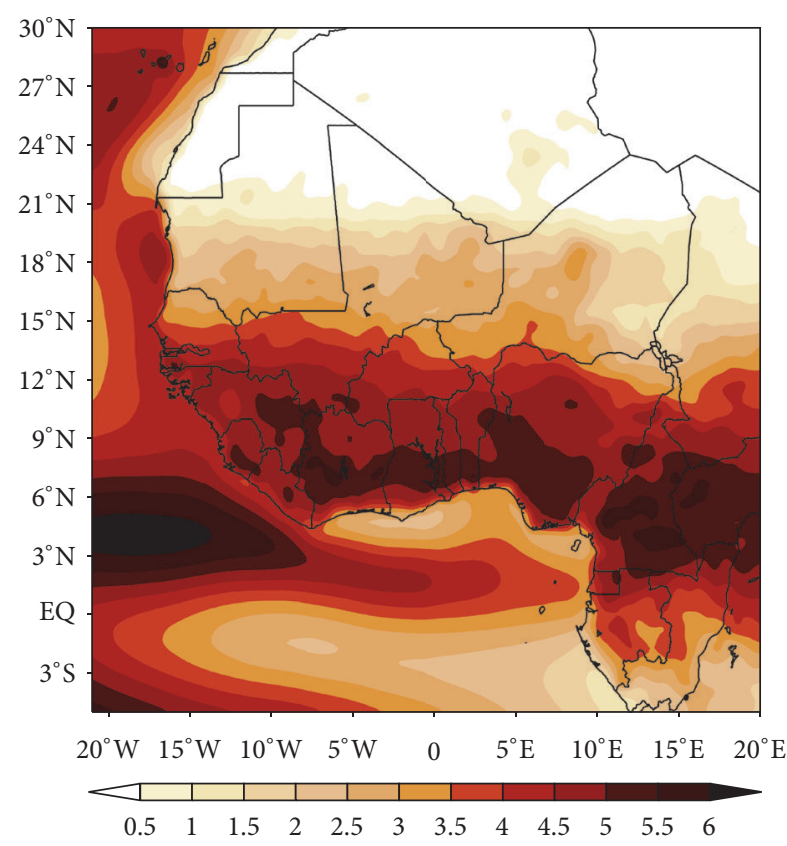

(b) JJAS RegCM4_REFORESTATION

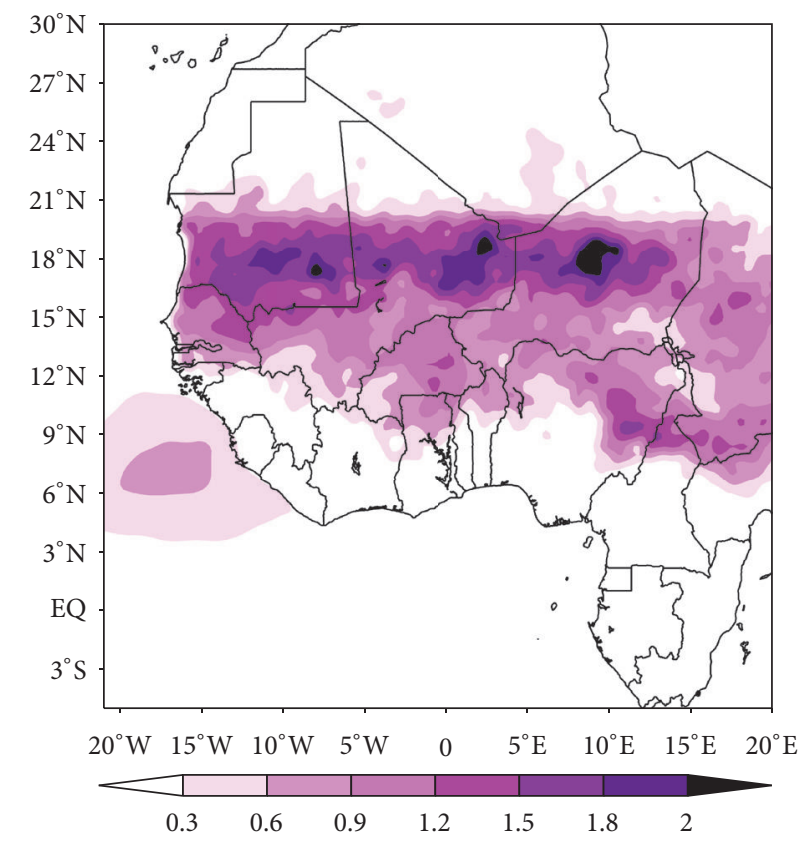

(c) JJAS RegCM4_REFORESTATION - RegCM4

FIGURE 5: Mean summer evapotranspiration $\left(\mathrm{cg} / \mathrm{m}^{2} / \mathrm{s}\right)$ averaged from 2003 to 2009 over West Africa for both runs and their difference.

the impacts of the reforestation on West African rainfall variability.

The spatial distribution of the mean summer rainfall (JJAS) is displayed in Figure 4 for both versions (standard and the reforested versions) of the regional climate model RegCM4 and their difference. The two experiments well represent the zonal distribution of the rainfall and capture a band of strong precipitation between latitudes $5^{\circ} \mathrm{N}$ and $14^{\circ} \mathrm{N}$ with maxima located over the orographic regions: Fouta
Jallon mountains $\left(10^{\circ} \mathrm{N}, 13^{\circ} \mathrm{W}\right)$, Jos Plateau $\left(10^{\circ} \mathrm{N}, 7.5^{\circ} \mathrm{E}\right)$, and Cameroon highlands $\left(6^{\circ} \mathrm{N}, 12^{\circ} \mathrm{E}\right)$. The two runs exhibit a strong north-south gradient; rainfall decreases from south to north with weak values located over the northern Sahel and the Sahara desert. The analysis of the difference between the reforested and the standard versions shows that the reforestation modifies the rainfall signal over various regions of West Africa by increasing it slightly (strongly) over the Sahel region including the reforested area (over and off the 


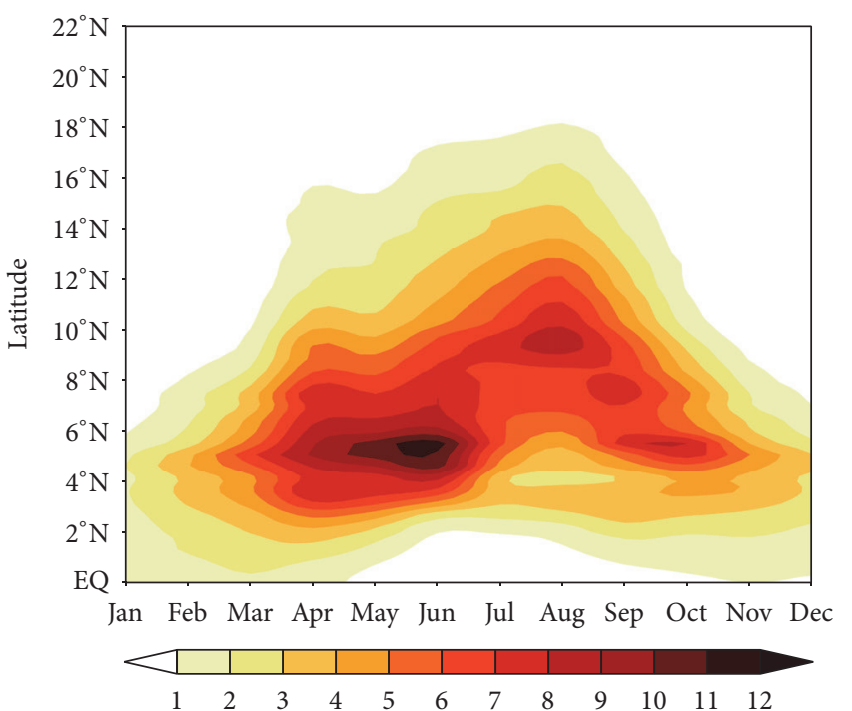

(a) Rainfall RegCM4

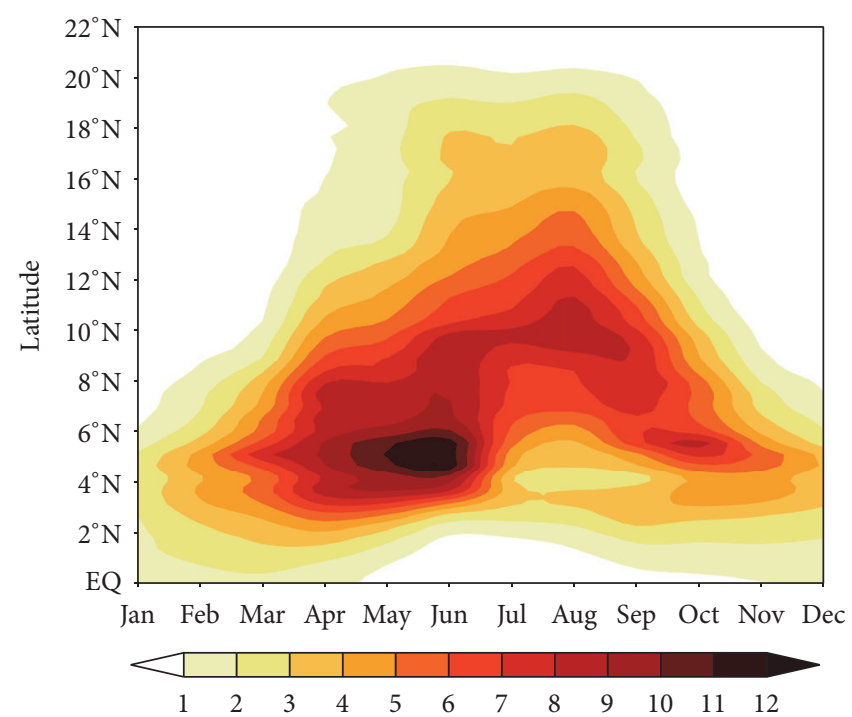

(b) Rainfall RegCM4_REFORESTATION

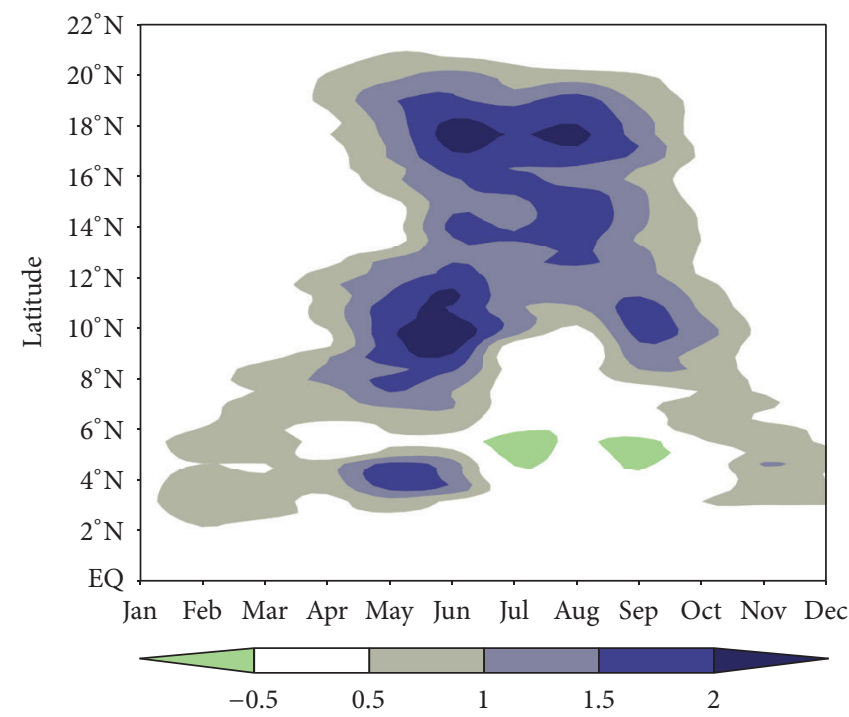

(c) Rainfall RegCM4_REFORESTATION - RegCM4

Figure 6: Hovmoëller diagram of rainfall averaged between $10^{\circ} \mathrm{W}$ and $10^{\circ} \mathrm{E}$ and from 2003 to 2009 for both runs and their difference.

Fouta Jallon highlands). This result confirms the remote effect of the reforestation which means that the change of vegetation cover can affect rainfall locally or on distant regions [49].

To better explain the impact of the reforestation on the rainfall, the summer (JJAS) evapotranspiration for both versions of the model and their difference is shown in Figure 5. The standard version of the RegCM4 model shows a dipolar structure with maxima located in the south over the Guinean coast and the ocean and the minima in the north over the Sahel and the Sahara desert. The reforested version well captures this dipolar structure. The reforestation tends to increase evapotranspiration over the Sahel with strong values located over the reforested area (Figure 5(c)) which is consistent with the rainfall increase over the same region. Furthermore, the mean summer (JJAS) relative humidity (\%) integrated in the lower layers (between 1000 and $850 \mathrm{hPa}$ ) shows stronger values over the Sahel region for the reforested version (figure not shown). This increase of the moisture content of the atmosphere combined with the wind dynamic may be partly responsible for the mean rainfall and extreme rainfall changes when reforesting the Sahel-Sahara interface.

In order to diagnose further the impacts of the reforestation on the West African climate, the Hovmoëller diagram of rainfall and temperature averaged between $10^{\circ} \mathrm{W}$ and $10^{\circ} \mathrm{E}$ and from 2003 to 2009 for both runs and their difference are displayed in Figures 6 and 7. The intraseasonal variability of rainfall over West Africa is mainly due to the south-north movement of the Intertropical Convergence Zone (ITCZ) which is characterized by a succession of active phases and pauses of convective activity. The rainy season over West Africa has three distinct phases: the preonset (installation phase), the onset (period of heavy rain over the Sahel region), 


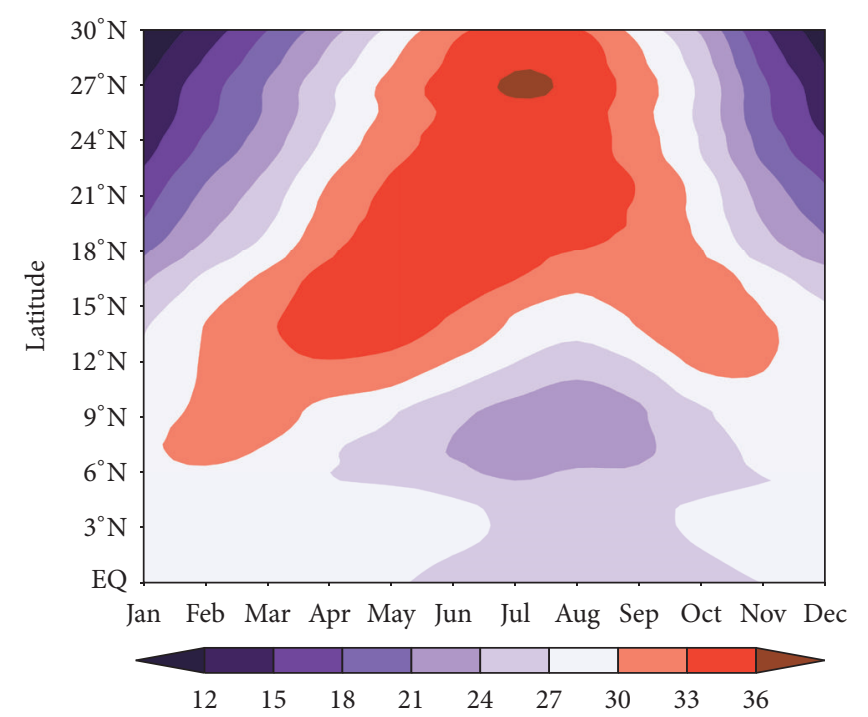

(a) $\mathrm{RegCM} 4$

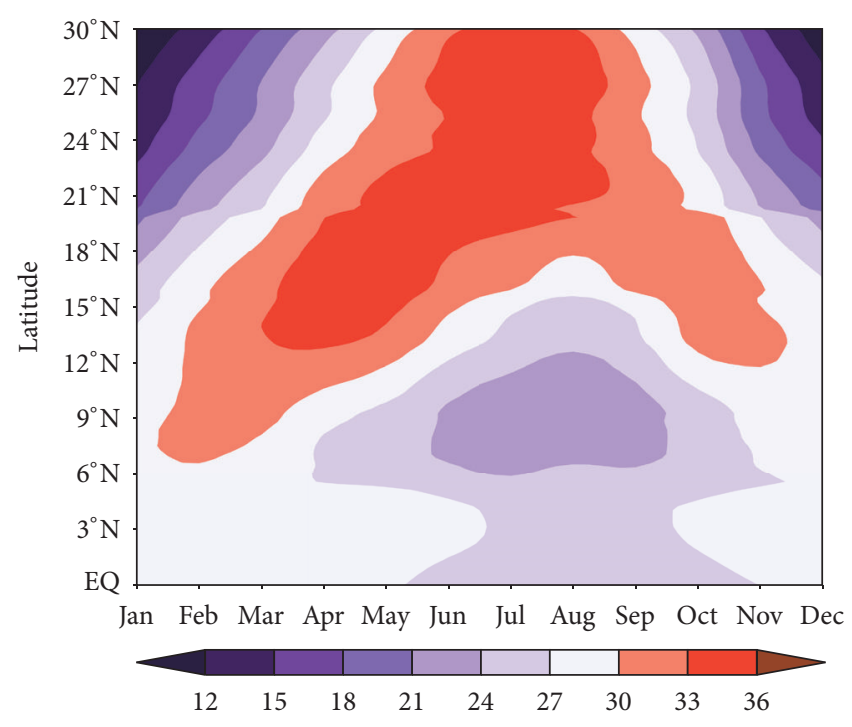

(b) RegCM4_REFORESTATION

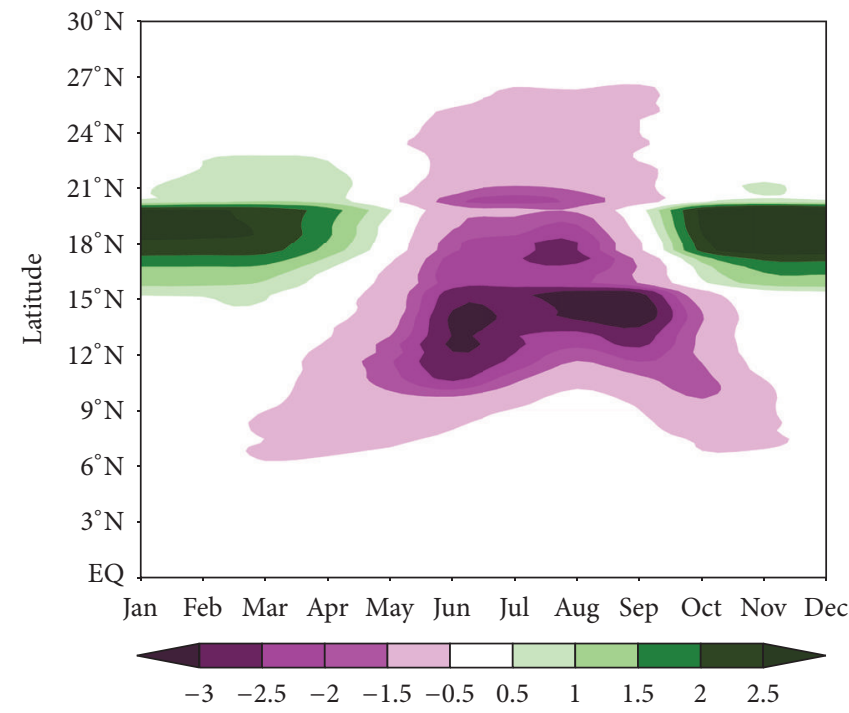

(c) RegCM4_REFORESTATION - RegCM4

Figure 7: Hovmoëller diagram of surface temperature averaged between $10^{\circ} \mathrm{W}$ and $10^{\circ} \mathrm{E}$ and from 2003 to 2009 for both runs and their difference.

and the withdrawal to the south of the rain band. The two experiments (model runs) clearly show these characteristics of the West African monsoon. In the first phase, the rainfall maximum remains centered south of $5^{\circ} \mathrm{N}$ until the end of June, after which the rainfall rates diminish.

After that, the rainfall increases near and north of $10^{\circ} \mathrm{N}$. This is the start of the rainy season over the Sahel region with the highest rainfall rates observed in August. The two model experiments well capture the first rainy season over the Guinea zone from March to June. This season is characterized by the northward extension of the rain band from the coasts to about $5^{\circ} \mathrm{N}$.

The monsoon jump occurs at the beginning of June in both versions of the model when the rain core moves rapidly northward to about $10^{\circ} \mathrm{N}$ corresponding to the Sahel region rainy season [50]. In September, the southward retreat of the rainfall belt is well simulated by the model (Figures 6(a) and 6(b)).

The analysis of the difference between the two versions shows that the reforestation tends to increase rainfall globally between $3^{\circ} \mathrm{N}$ and $20^{\circ} \mathrm{N}$ with a maximum during the monsoon onset period (from May to June) and the peak of Sahel rainfall season (from July to September) over the Sahel region and the reforested area. Surface temperature is also impacted by this land cover change. Figure 7 shows the Hovmoëller diagram of surface temperature averaged between $10^{\circ} \mathrm{W}$ and $10^{\circ} \mathrm{E}$ and from 2003 to 2009 for both runs and their difference over West Africa. When considering both experiments, the highest temperatures (above $33^{\circ} \mathrm{C}$ ) are recorded from March to September around $12^{\circ} \mathrm{N}$ (over the Sahel) and over the 


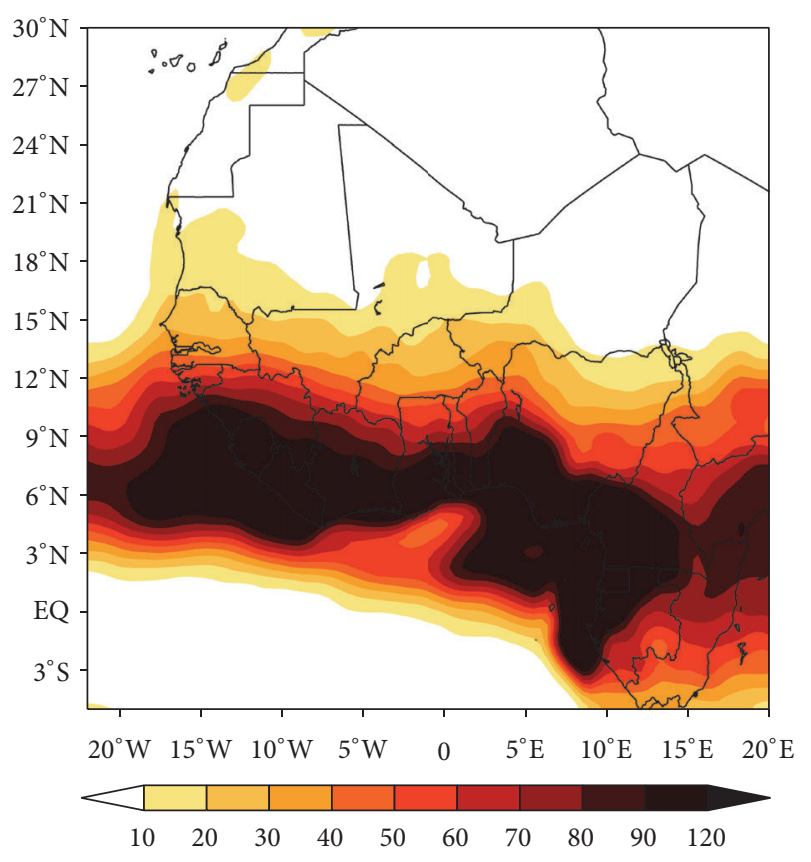

(a) RegCM4 JJAS $R>1 \mathrm{~mm}$

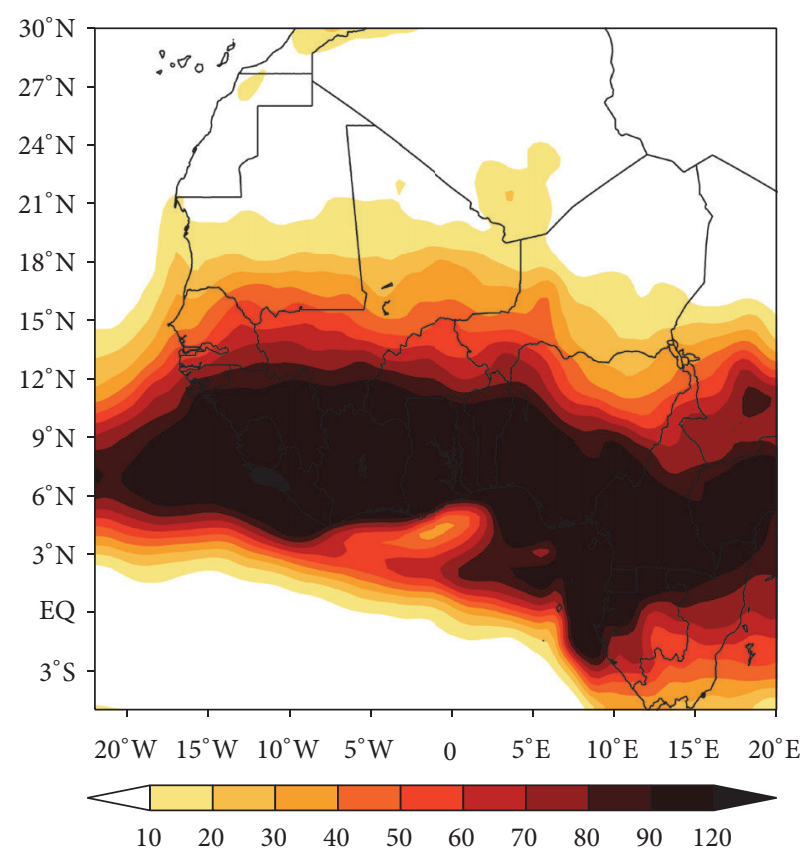

(b) RegCM4_REFORESTATION JJAS $R>1 \mathrm{~mm}$

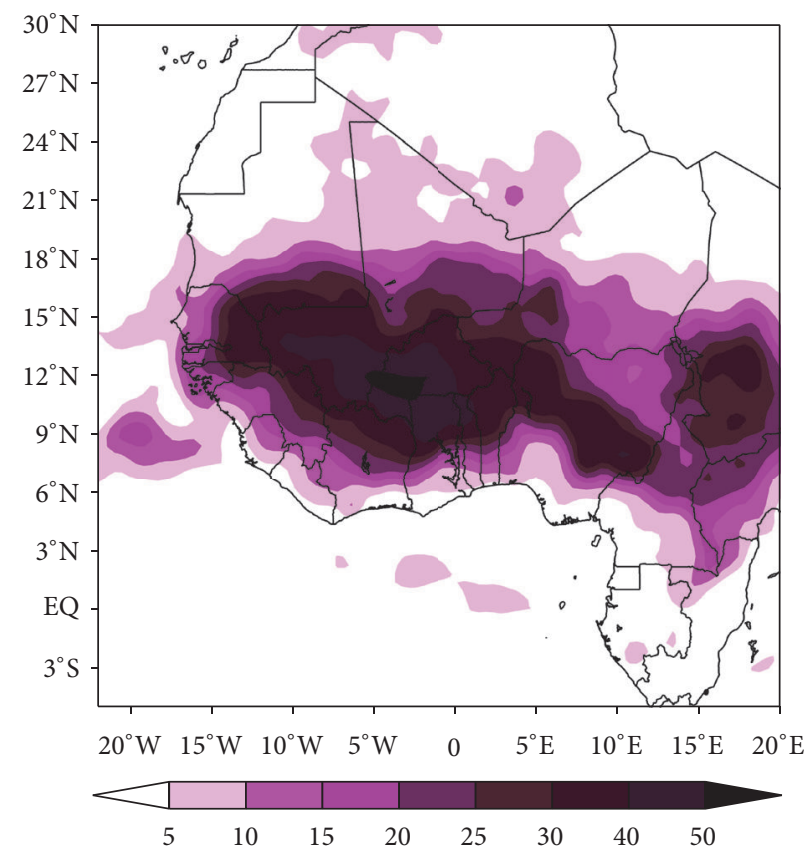

(c) RegCM4_REFORESTATION - RegCM4 JJAS $R>1 \mathrm{~mm}$

FIGURE 8: Number of rainy days (daily cumulative precipitation greater than $1 \mathrm{~mm}$ ) during the summer period (JJAS) averaged from 2003 to 2009 for both runs and their difference.

Sahara desert. A southward shift of temperature maxima is observed in September. The two runs show low temperature over Guinean coast (around $6^{\circ} \mathrm{N}$ ) from June to September. The analysis of the difference between the reforested and the standard versions shows a decrease of temperature over the Sahel and the reforested zone (Sahel-Sahara interface) during the summer period (June to September). This decrease is stronger (more than $-3^{\circ} \mathrm{C}$ ) between the latitudes $12^{\circ} \mathrm{N}$ and $15^{\circ} \mathrm{N}$; this is consistent with the observed rainfall increase simulated over that region (Figure 4(c)) which tends to create evaporative cooling over that domain but also with the moisture increase simulated over the reforested area (figure not shown). Furthermore, the temperature increase from January to March and from October to December between 


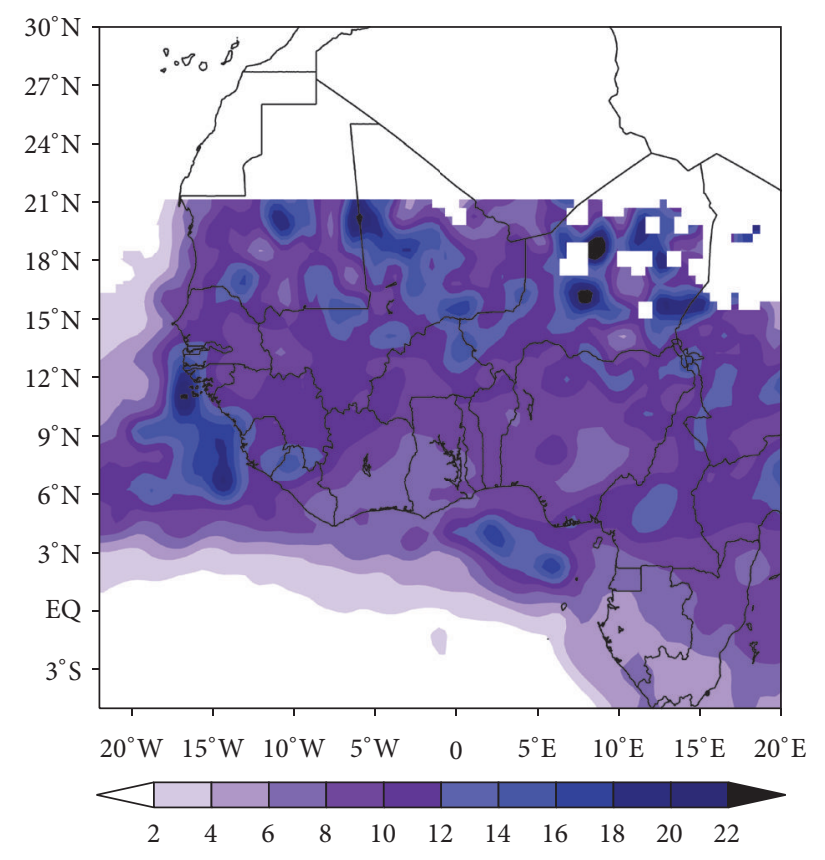

(a) RegCM4 JJAS SDII

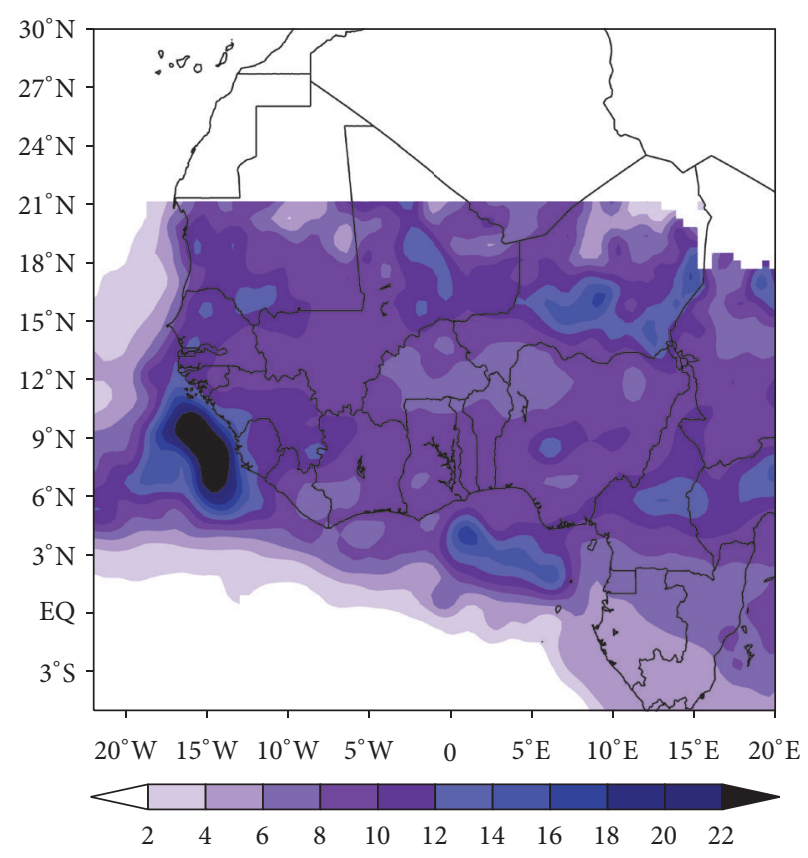

(b) RegCM4_REFORESTATION JJAS SDII

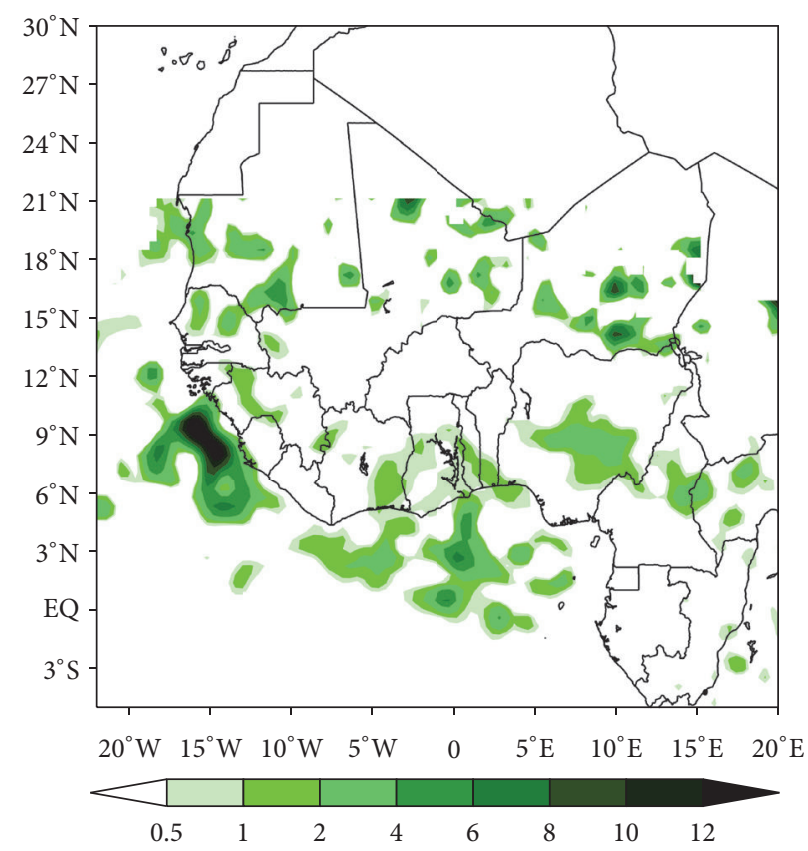

(c) JJAS (RegCM4_REFORESTATION - RegCM4)

Figure 9: Mean summer simple daily intensity index (mm/day) for both runs and their difference averaged from 2003 to 2009.

$15^{\circ} \mathrm{N}$ and $20^{\circ} \mathrm{N}$ may be linked to the strong increase of the sensible heat flux over the same region and during the same period (figure not shown).

3.2. Analysis of Extreme Rainfall Events. Climate change and change in extreme precipitation events would pose a serious threat to human health and welfare particularly in low income countries such as those of West Africa. Indeed the last report of the IPCC (2013) shows that the global warming will cause the increase of extreme weather events which will affect the populations with an increase of their vulnerability. Figure 8 shows the number of rainy days (number of days with a daily cumulative precipitation greater than $1 \mathrm{~mm}$ ) averaged over the peak of the summer period (June-July-AugustSeptember) from 2003 to 2009 for the two runs and their difference. The two experiments show a maximum of the number of rainy days along the Intertropical Convergence Zone (ITCZ) especially over the mountainous areas, near and 


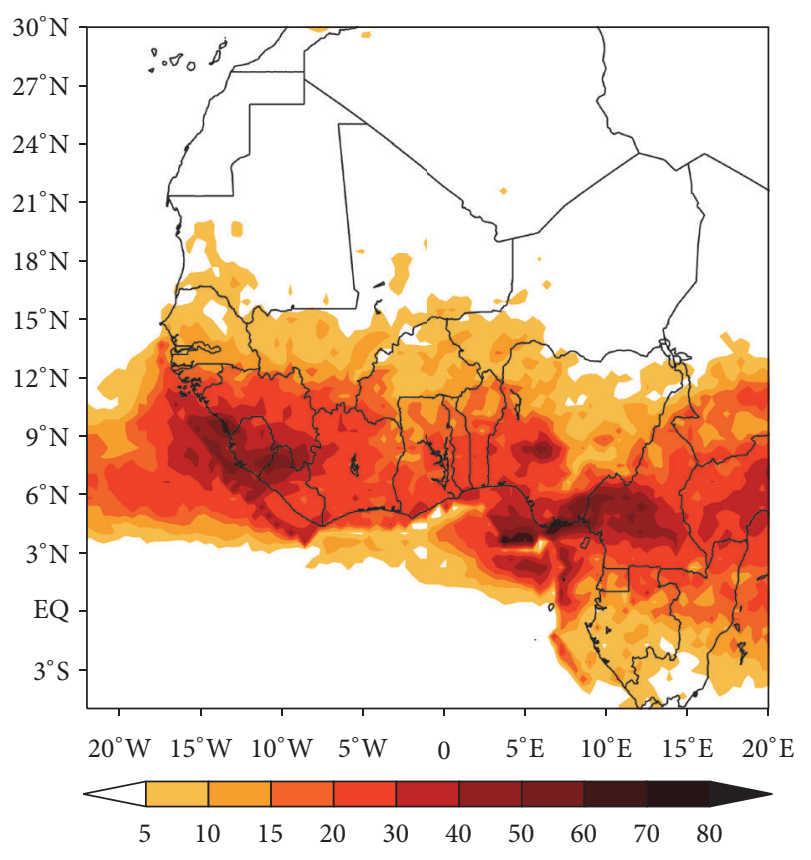

(a) RegCM4 JJAS $R \geq 10 \mathrm{~mm}$

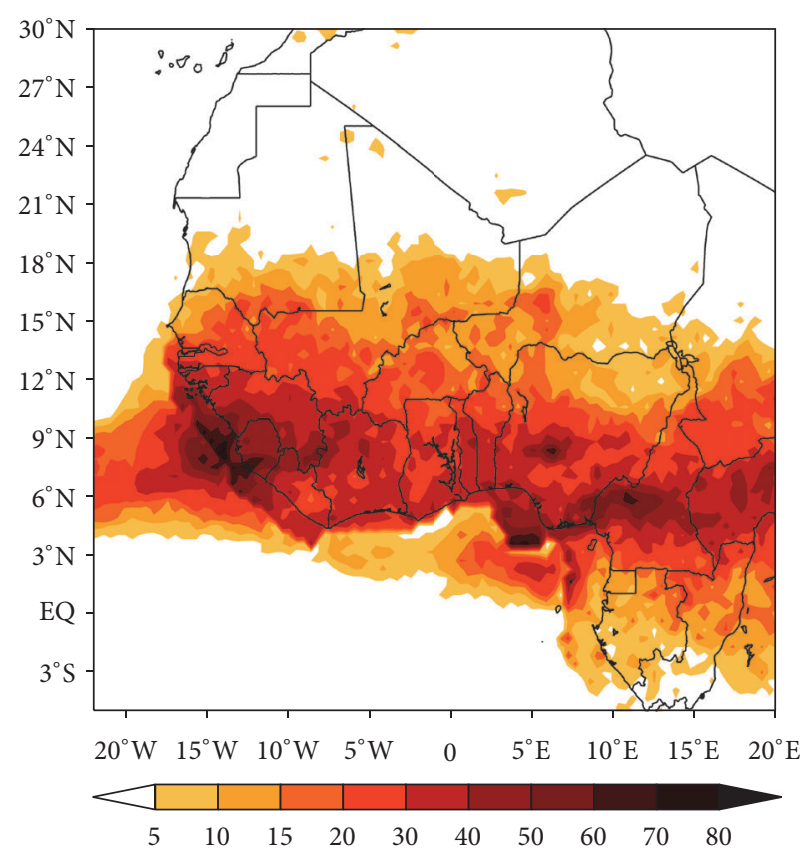

(b) RegCM4_REFORESTATION JJAS $R \geq 10 \mathrm{~mm}$

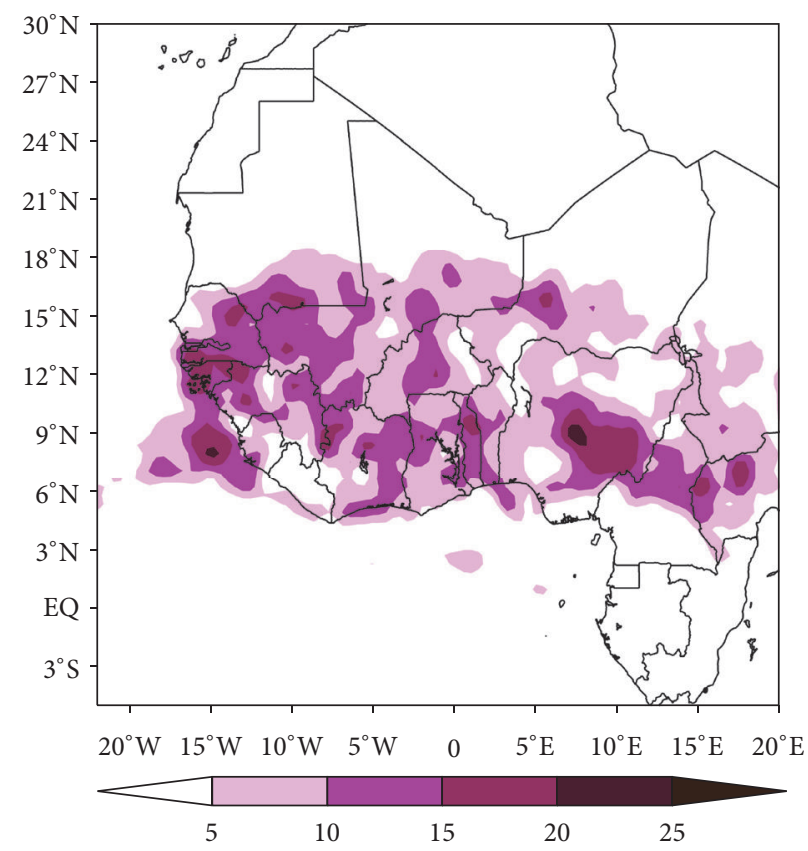

(c) RegCM4_REFORESTATION - RegCM4 JJAS $R \geq 10 \mathrm{~mm}$

FIGURE 10: Mean summer frequency of intense rainfall days $(R \geq 10 \mathrm{~mm})$ for both runs and their difference averaged from 2003 to 2009 .

off the Fouta Jallon highlands (over the ocean). A northsouth gradient with the number of rainfall events decreasing on both sides of the ITCZ is also noticed. The reforested run shows similar patterns to the standard version with a stronger northward extension of rainfall events. The analysis of the difference between the reforested and the standard versions (Figure 8(c)) shows that the reforestation tends to increase the number of rainy days roughly over a region located between the latitudes $6^{\circ} \mathrm{N}$ and $17.5^{\circ} \mathrm{N}$ and west of $5^{\circ} \mathrm{E}$ and especially over the Sahel and the reforested zone. This increase is associated with an increase of the evapotranspiration over the reforested zone (Figure $7(\mathrm{c})$ ). The spatial distribution of the simple daily intensity index (SDII) which is calculated as the mean intensity of the number of rainy days is displayed in Figure 9 for the two runs and their difference. Both runs show higher rainfall intensities over the Sahel region and the orographic areas (especially Guinea highlands) along the ITCZ during wet days. The analysis of the difference between 


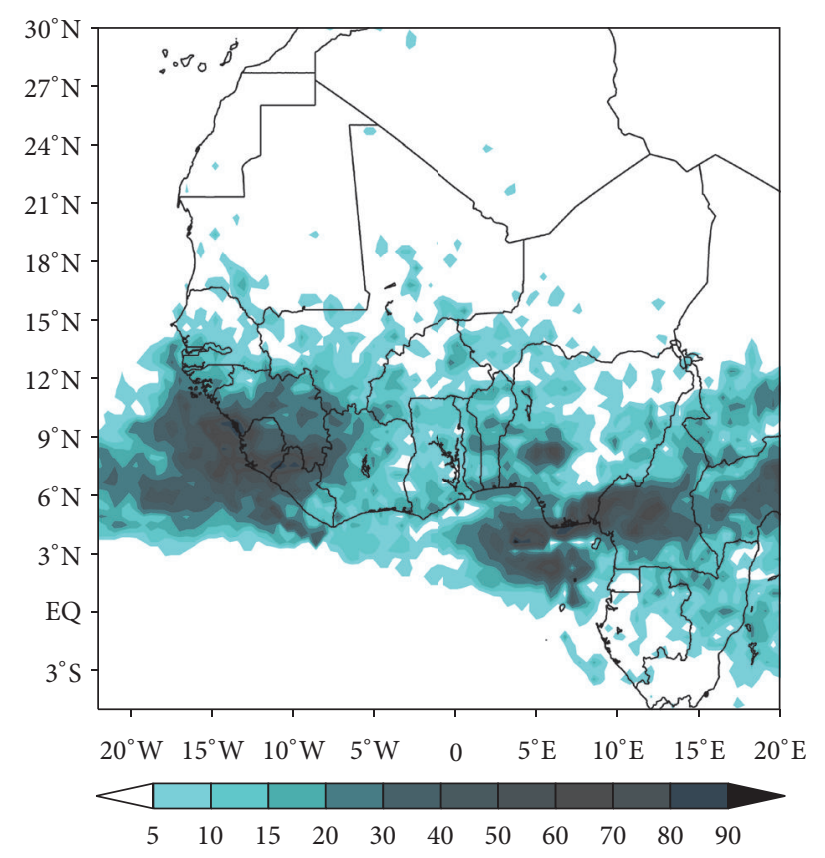

(a) RegCM4 JJAS

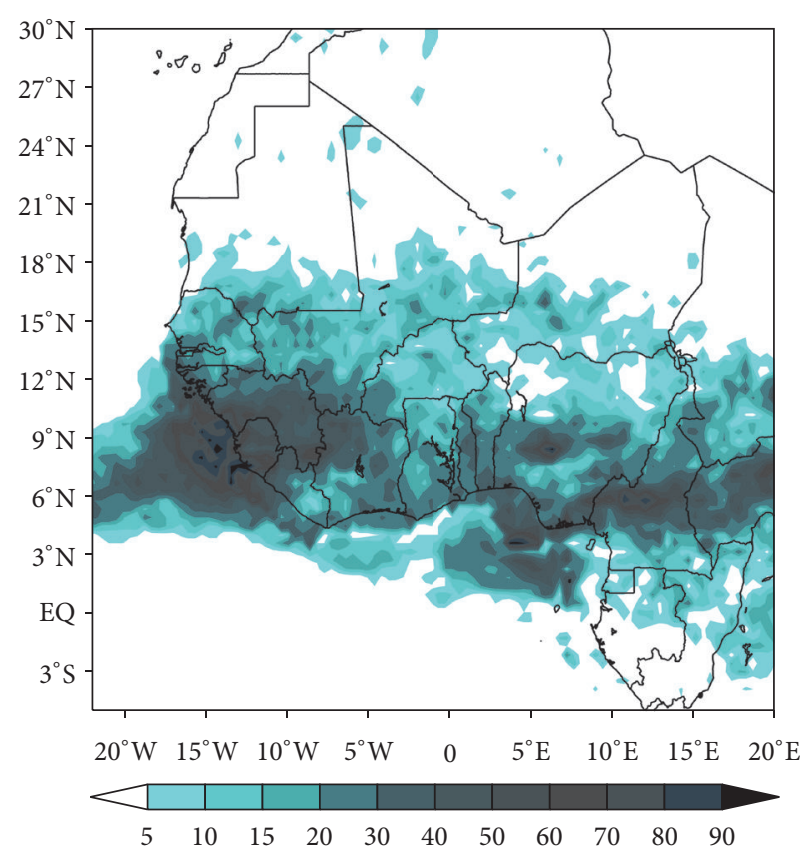

(b) RegCM4_REFORESTATION JJAS

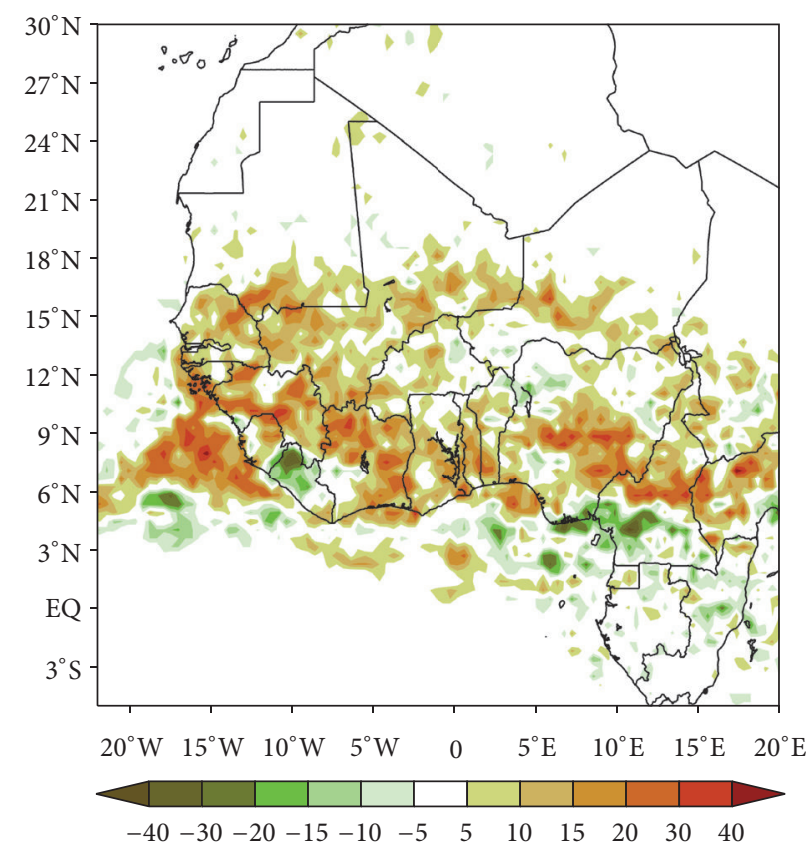

(c) JJAS (RegCM4_REFORESTATION - RegCM4)

FIGURE 11: Maximum 5-day precipitation accumulations exceeding $50 \mathrm{~mm} /$ day (RX5day) for both runs and their difference averaged from 2003 to 2009.

the two versions (Figure 9(c)) shows a clear signal (rainfall increase) only off the Guinea highlands and a slight increase over the Jos Plateau and the Gulf of Guinea despite the fact that a strong difference over a large region was noticed when considering the impact of the reforestation on the number of rainy events suggesting that a large part of these events may have weak intensities.

The next step of this work is to diagnose the spatial variability of extreme rainfall events that plays an important role in water resources availability, agriculture and pastoralism which remain the pillars of the economy of West African countries. The frequency of the intense rainfall events $(R \geq$ $10 \mathrm{~mm}$ /day) is displayed in Figure 10. Strong values of the intense rainfall events are concentrated over the orographic regions and the ocean. The spatial distribution shows a north-south gradient. This distribution is the same for the two runs. The analysis of the difference between the reforested and the standard versions (Figure 10(c)) shows an increase 


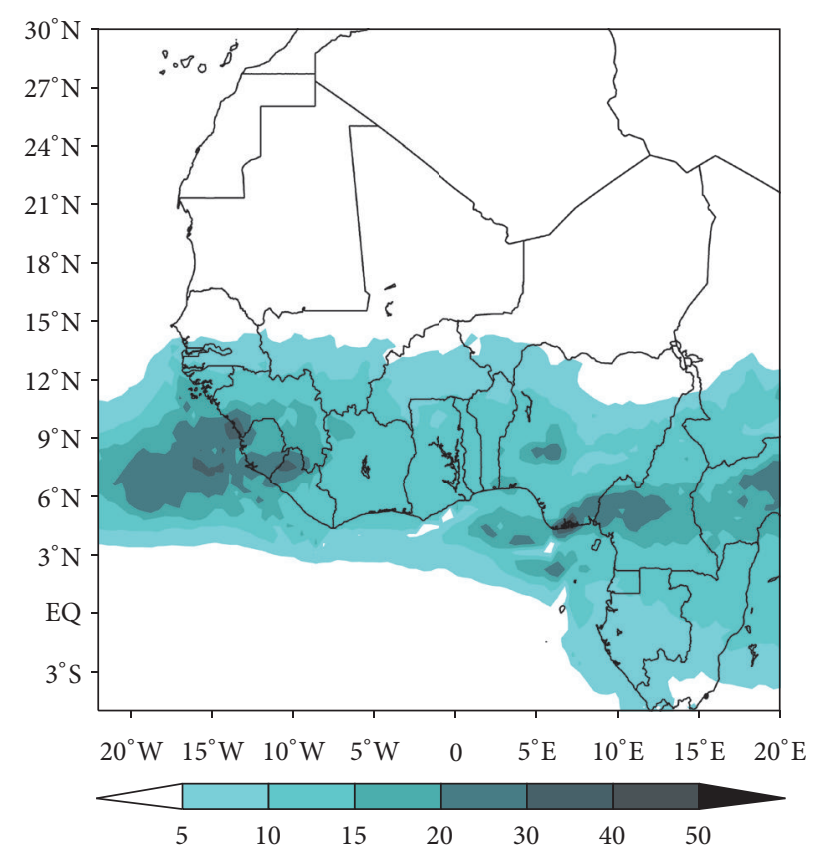

(a) RegCM4 JJAS

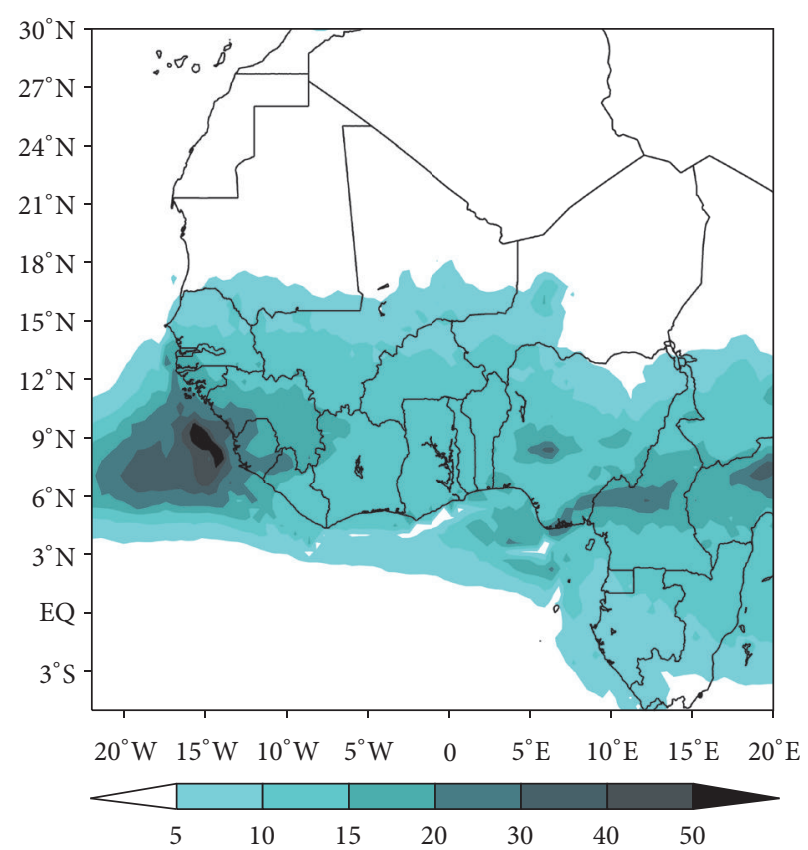

(b) RegCM4_REFORESTATION JJAS

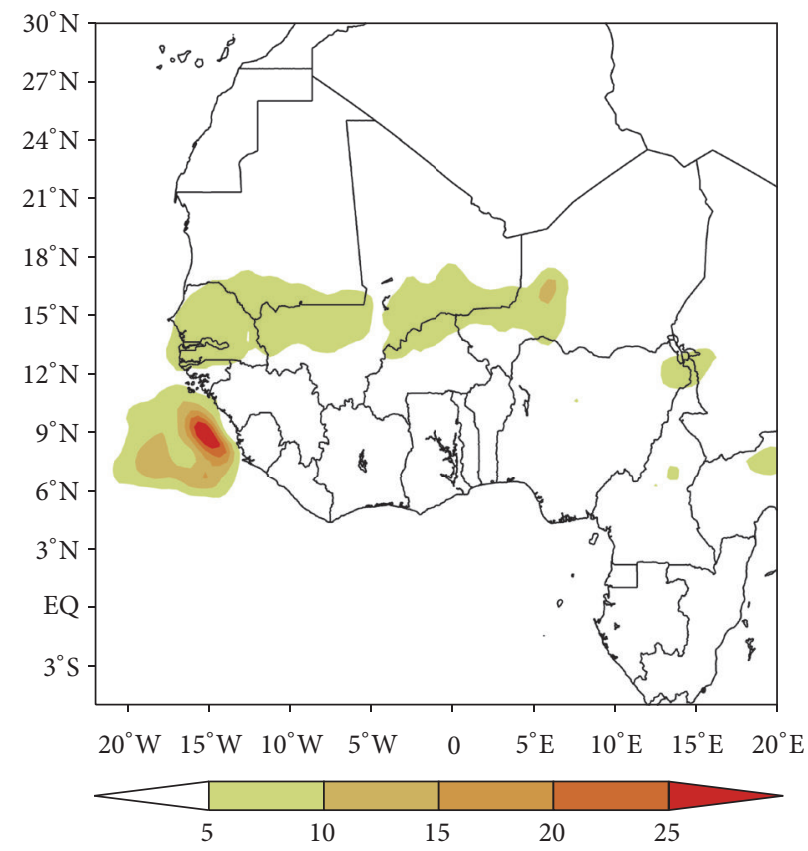

(c) JJAS (RegCM4_REFORESTATION - RegCM4)

Figure 12: Mean JJAS 90th percentile of daily rainfall events ( $\mathrm{mm} /$ day) over West Africa for both runs and their difference averaged from 2003 to 2009.

of the frequency of the intense rainfall events over the Sahel including the southern part of the reforested zone and over the orographic regions. This distribution is similar to the pattern of rainy days suggesting that the reforestation may impact more strongly these intense rainfall events.

When considering the frequency of the very intense rainfall events $(R \geq 20 \mathrm{~mm} /$ day $)$, the two runs show a discontinuous structure (figure not shown) with strong values localized over the western part (over the ocean and Fouta Jallon mountains) and over the eastern part of the domain (over Jos Plateau and Cameroon highlands). The analysis of the difference between the reforested and the standard versions shows an increase of the heavy rainfall events only off the Fouta Jallon highlands.

In order to go deeper in the diagnosis of the extreme rainfall events, the maximum cumulative pentad RX5day 


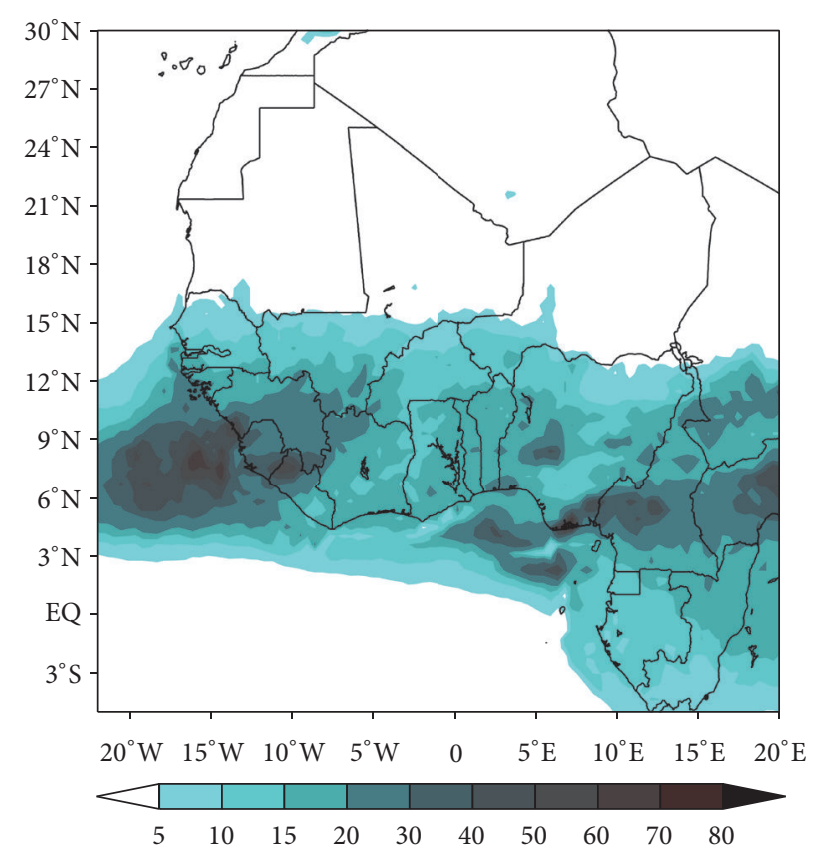

(a) RegCM4 JJAS

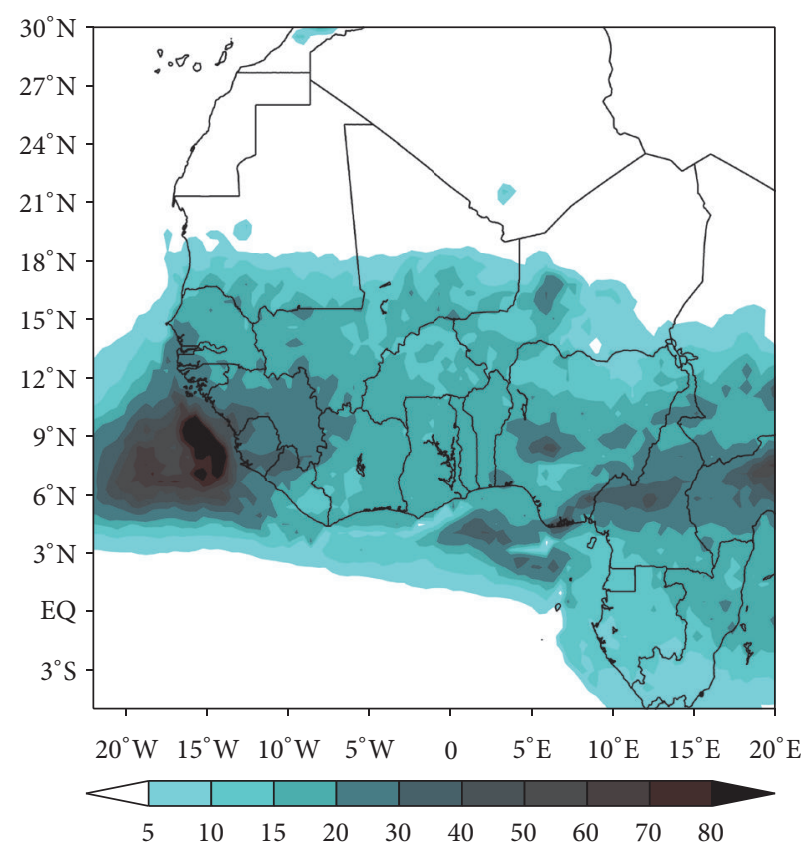

(b) RegCM4_REFORESTATION JJAS

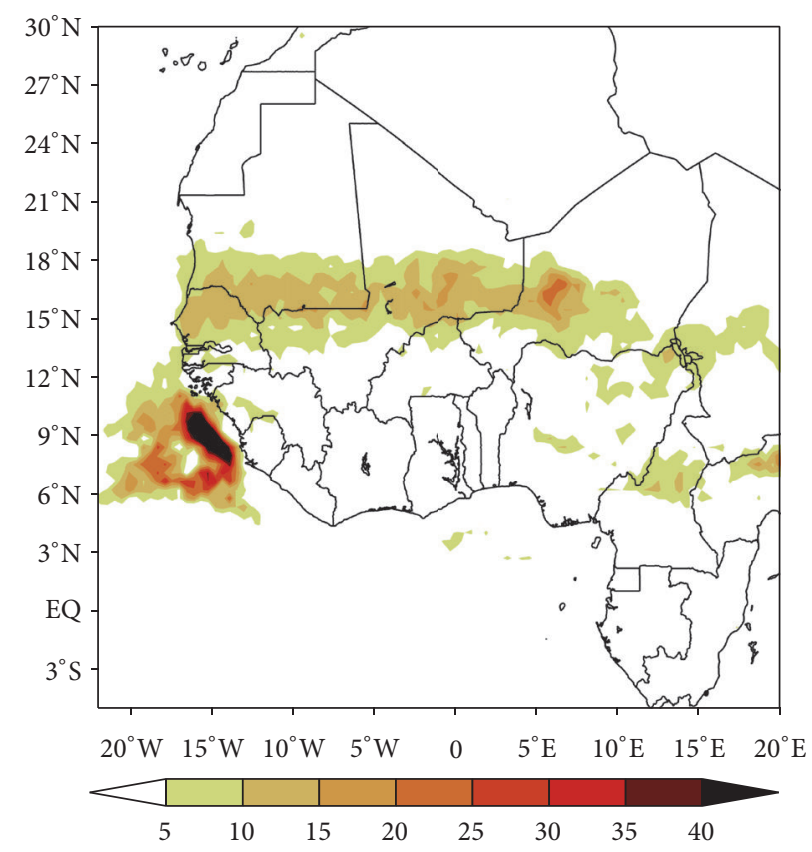

(c) JJAS (RegCM4_REFORESTATION - RegCM4)

FIGURE 13: Mean JJAS 95th percentile of daily rainfall events ( $\mathrm{mm} /$ day) over West Africa for both runs and their difference averaged from 2003 to 2009.

(five consecutive rainy days with precipitation accumulation exceeding $50 \mathrm{~mm}$ ) is calculated and displayed in Figure 11. These strong rainfall events are known to be favorable to flooding and therefore they are a major concern for local populations. Strong values are located over a latitudinal band between $3^{\circ} \mathrm{N}$ and $12^{\circ} \mathrm{N}$ especially over orographic regions (Fouta Jallon mountains; Jos Plateau and Cameroon highlands).
The analysis of the difference between the reforested and the standard versions shows an increase of the maximum cumulative pentad (RX5day) over the southern part of the reforested zone, the western Sahel, and the Atlantic ocean (around $7^{\circ} \mathrm{N}$ ), and orographic regions such as the Fouta Jallon. The increase of these intense precipitation events is consistent not only with changes in overall precipitation but also with evapotranspiration increasing. This result is in line 


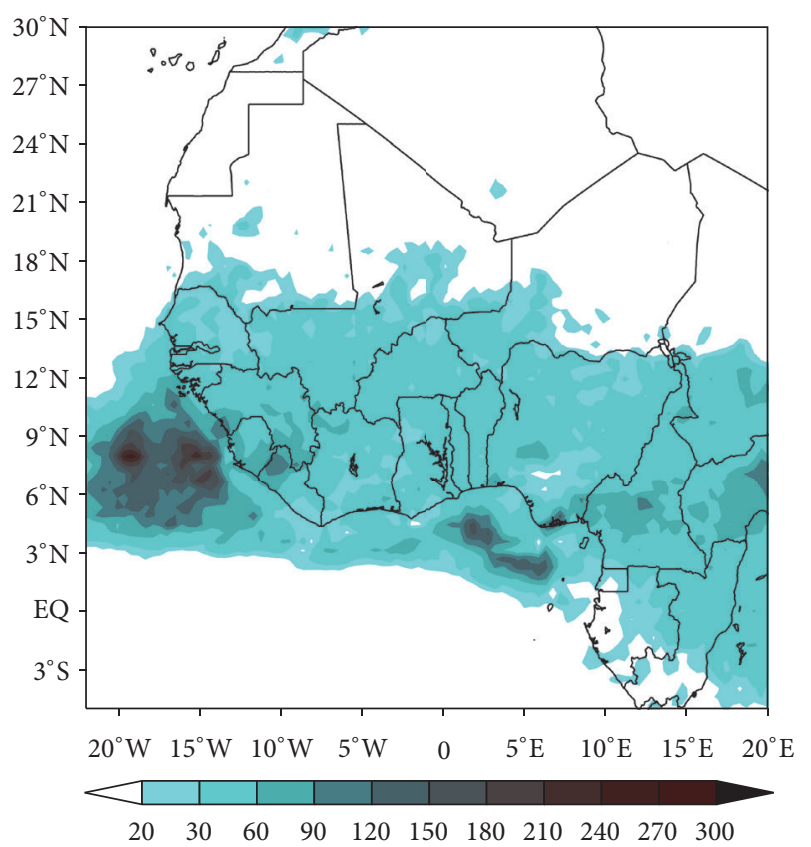

(a) RegCM4 JJAS

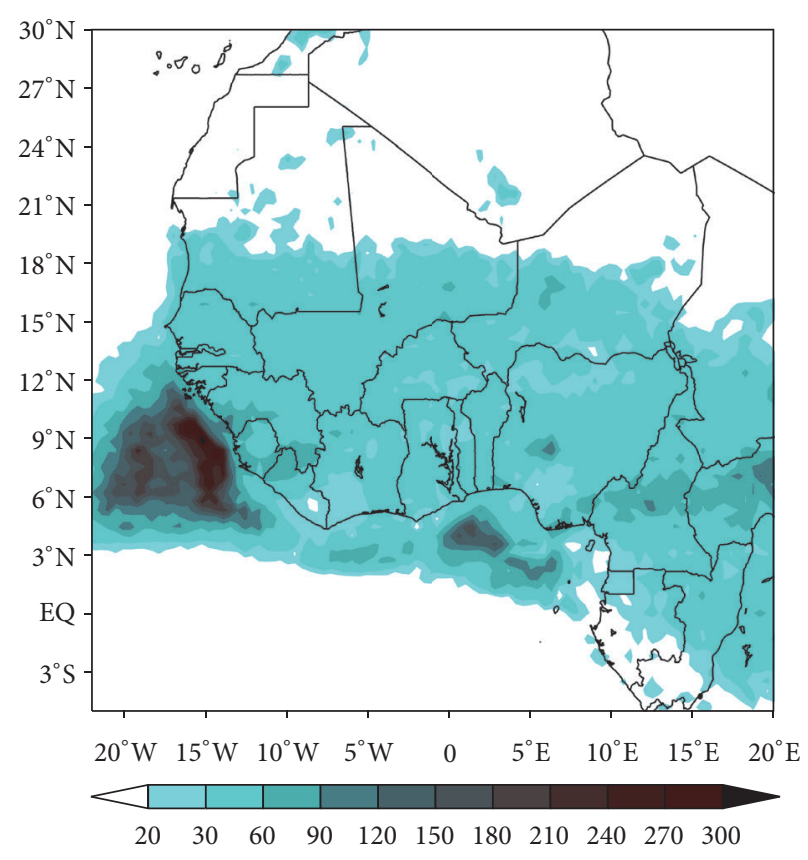

(b) RegCM4_REFORESTATION JJAS

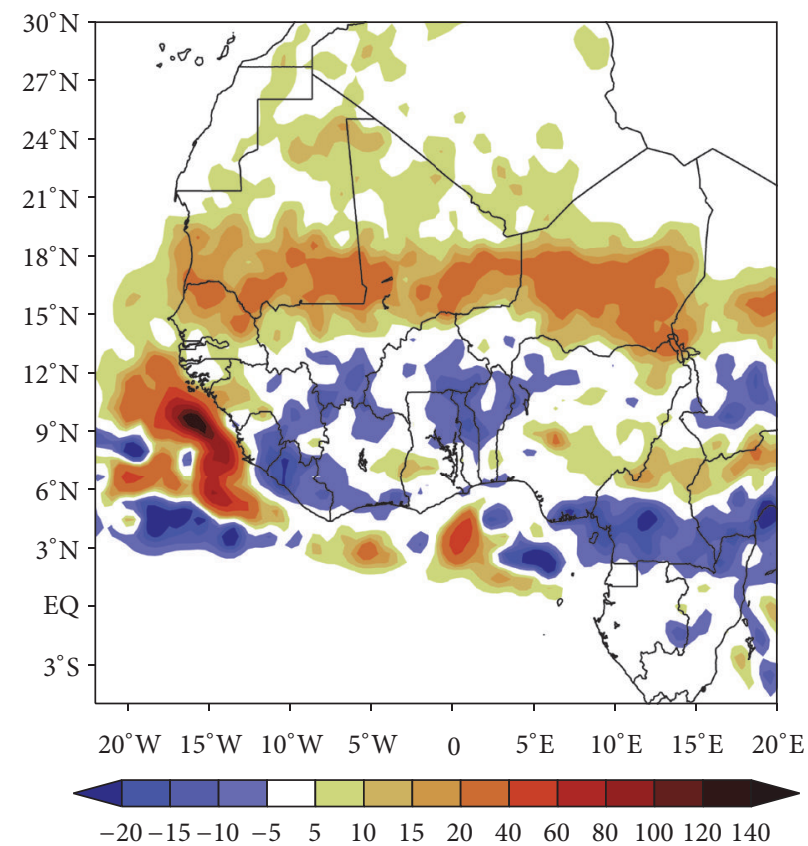

(c) JJAS (RegCM4_REFORESTATION - RegCM4)

FIGURE 14: Mean JJAS 99th percentile of daily rainfall events (mm/day) over West Africa for both runs and their difference averaged from 2003 to 2009.

with the previous ones which suggested that the reforestation influences more strongly intense rainfall events.

The extreme rainfall event that is based on the mean 90th percentile is shown in Figure 12. The standard version of RegCM4 exhibits a zonal distribution similar to the mean summer rainfall with values decreasing from the South to the North. The maxima are located over the ocean and the orographic regions: Fouta Jallon mountains and Jos and Cameroon highlands. The reforested version (RegCM4_REFORESTATION) shows a similar zonal distribution of rainfall as well as its maxima localization. The reforestation increases the mean 90th percentile of daily rainfall events over Senegal and Mali-Mauritania border and more strongly off the Guinea highlands.

The very wet days known as the mean 95th percentile are displayed in Figure 13. The standard version of the model 


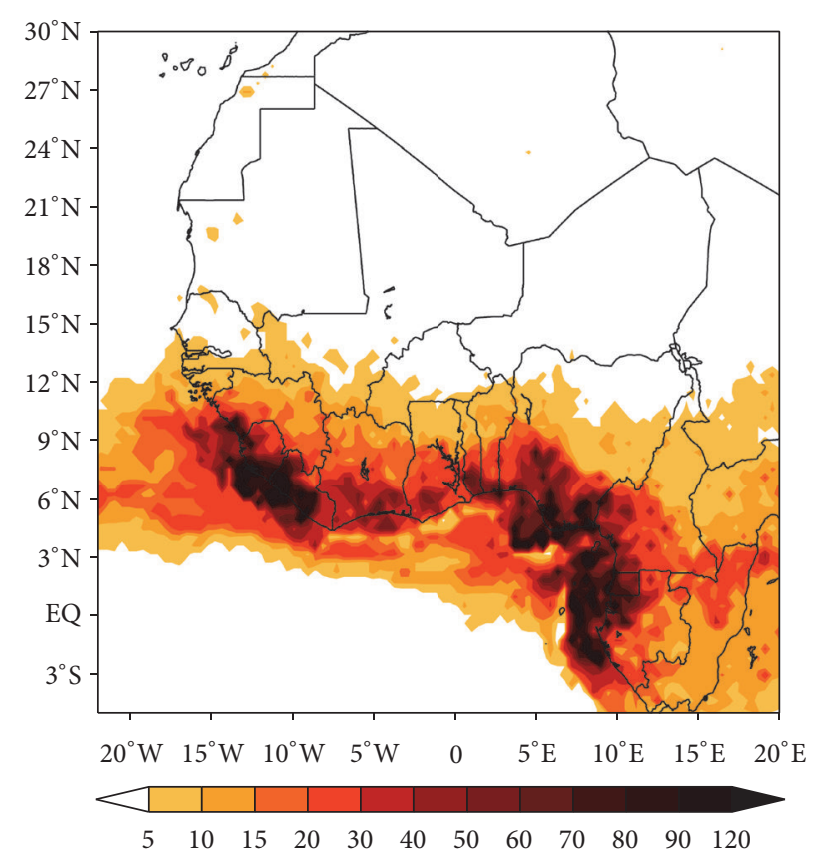

(a) RegCM4 JJAS CWD

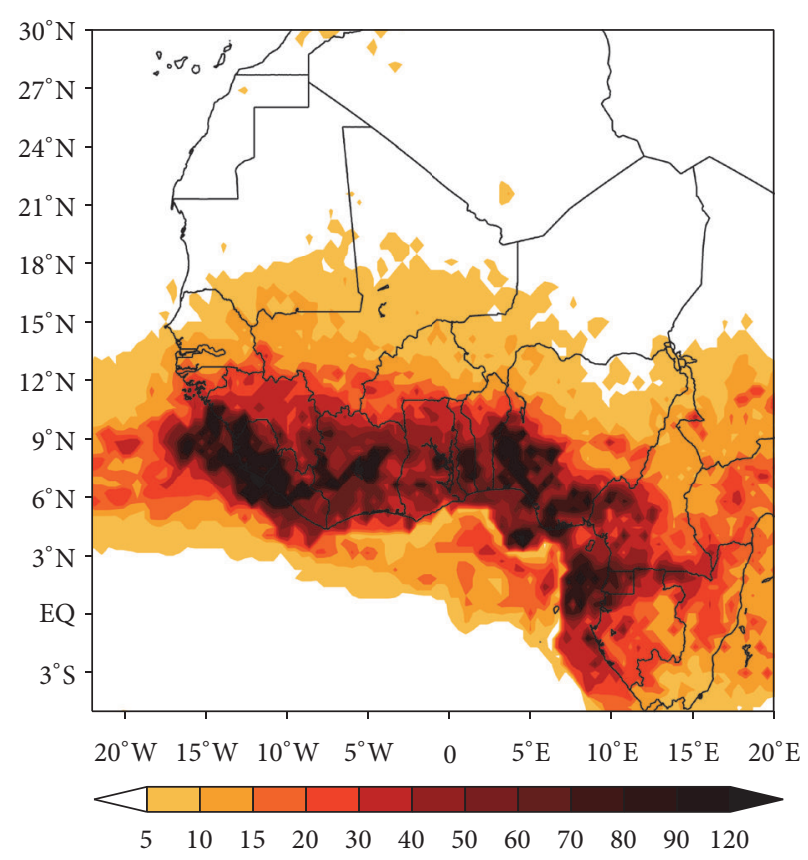

(b) RegCM4_REFORESTATION JJAS CWD

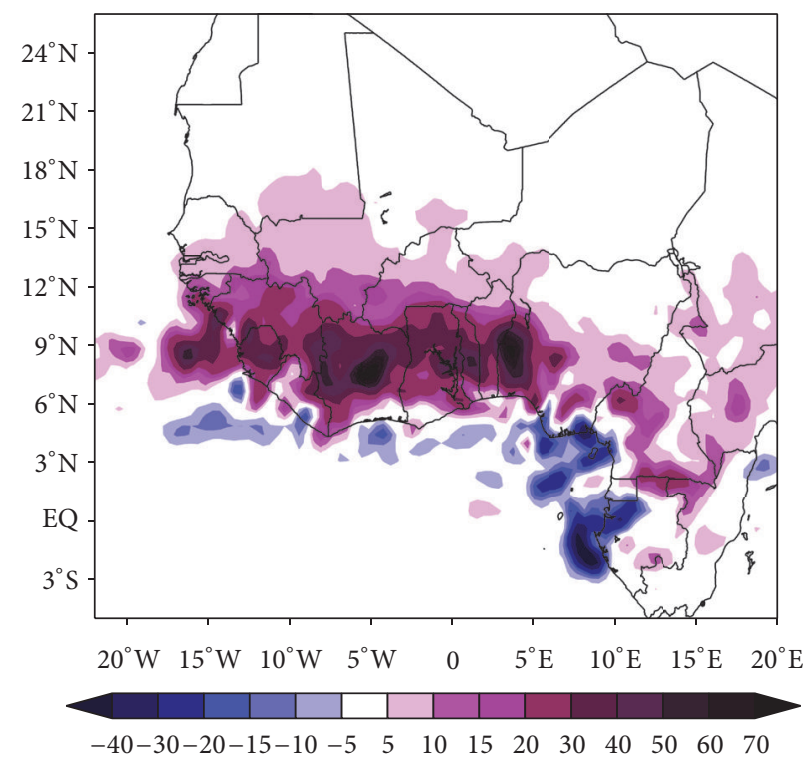

(c) RegCM4_REFORESTATION - RegCM4 JJAS CWD

FIGURE 15: Maximum length of the consecutive wet days (CWD) for both runs and their difference averaged from 2003 to 2009.

shows a spatial distribution of the mean 95th percentile similar to the reforested one. In fact, the two runs place the maximum rainfall along the Intertropical Convergence Zone (ITCZ), over the oceanic and orographic regions. The analysis of the difference between the reforested and the standard versions (Figure 13(c)) shows an increase of the mean 95th percentile over south of the reforested zone and off the Guinea highlands over the ocean.

The 99th percentile of daily rainfall events (or extremely wet days) is displayed in Figure 14. The standard version of RegCM4 exhibits a zonal distribution of precipitation with maxima localized over the ocean and the orographic regions: Fouta Jallon mountains and Cameroon highlands. The reforested version well reproduces this zonal distribution of the mean 99th percentile of daily rainfall and the maxima. The difference between the reforested and the standard versions shows generally an increase of the mean 99th percentile over the reforested zone and the oceanic region. However some regions like the southern part of Cameroon are characterized by a decrease of the 99th percentile. Finally, this percentile analysis highlights the fact that the impact of the reforestation is stronger when the threshold increases suggesting again 


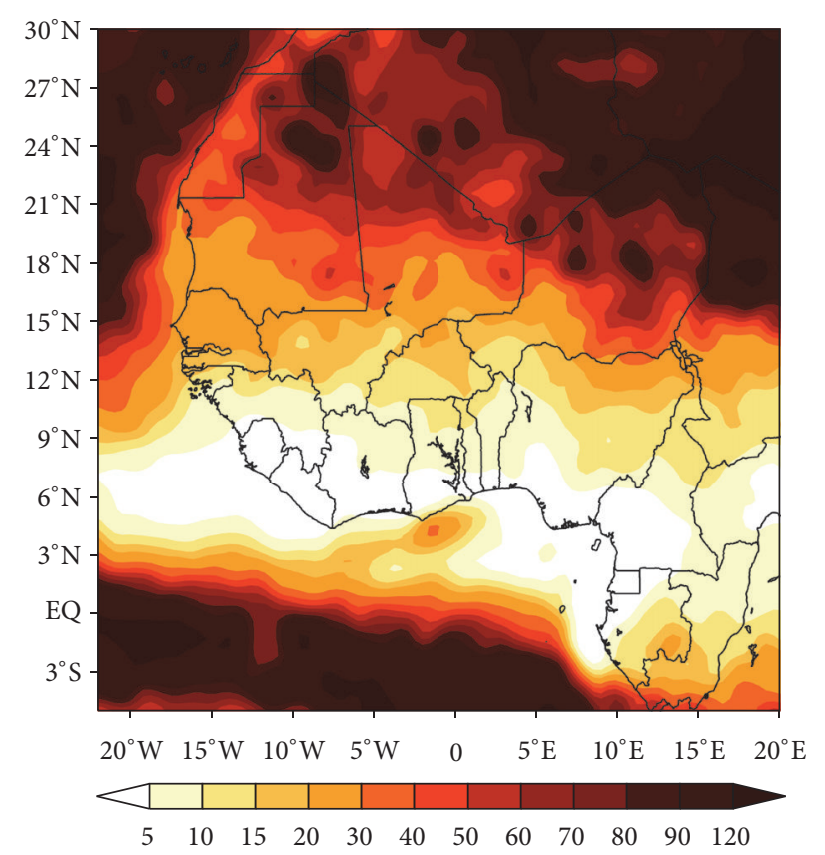

(a) RegCM4 JJAS CDD

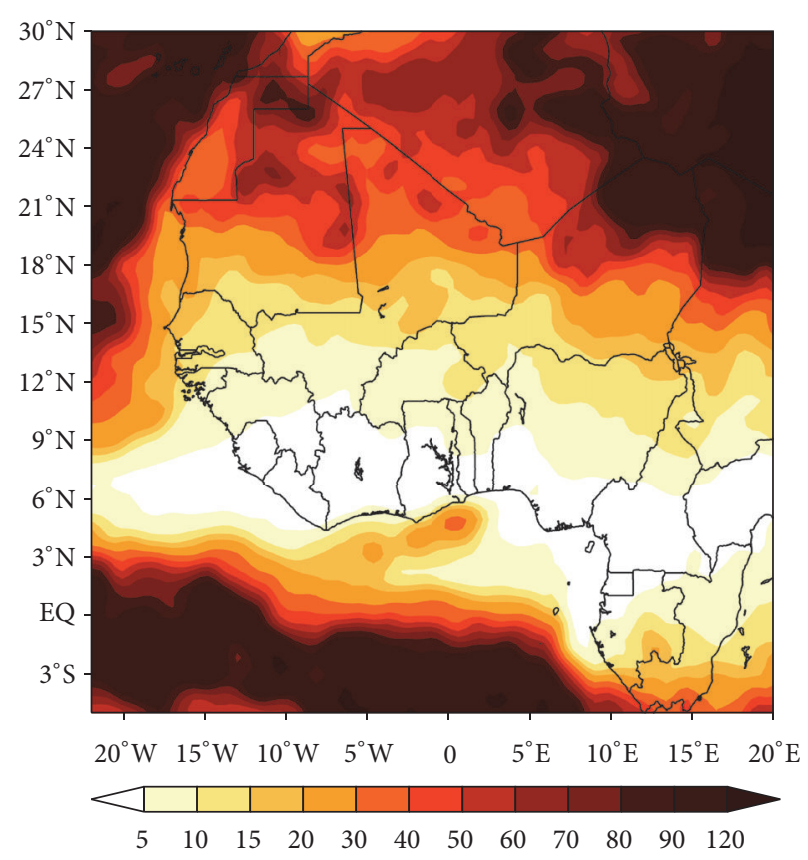

(b) RegCM4_REFORESTATION JJAS CDD

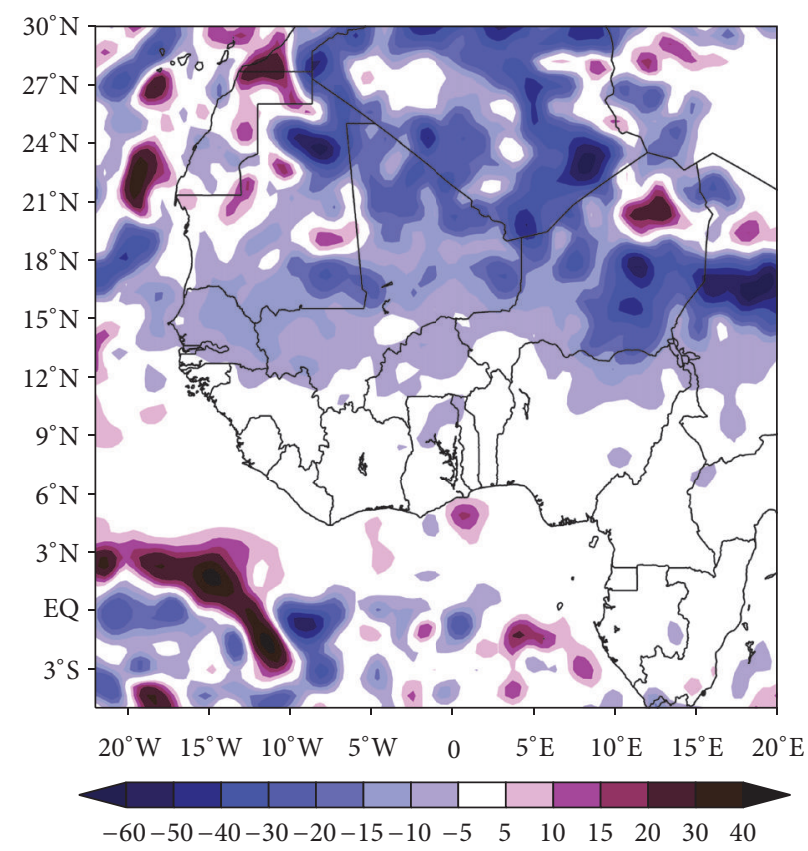

(c) RegCM4_REFORESTATION - RegCM4 JJAS CDD

FIGURE 16: Maximum length of the consecutive dry days (CDD) for both runs and their difference averaged from 2003 to 2009.

that this land cover change highly influences extreme rainfall events.

Other important parameters for the assessment of the extreme hydroclimatic conditions of a region are the maximum duration of the consecutive wet days (CWD) and the consecutive dry days (CDD). These parameters which are also known to be crucial for the agriculture are displayed in Figures 15 and 16 for the two runs and their difference. The spatial distribution of the consecutive wet days shown in Figure 15 is broadly consistent with the number of rainy days shown in Figure 8. Strong values are observed over the orographic regions (Fouta Jallon highlands; Jos Plateau and Cameroon highlands) and the Guinean coast. When considering the CDD, stronger values of the dry spell length (Figure 16) are recorded at the south and the north of the band swept by the Intertropical Convergence Zone (ITCZ). The shorter consecutive dry days are observed along the region of the maximum precipitation (ITCZ) and over orographic 
regions during the summer season. The reforestation causes an increase of the consecutive wet days over and off Fouta Jallon highlands and a decrease of the dry spell maximum duration over the northern Sahel and the reforested zone. This decrease of the maximum duration of CDD over the reforested area may be favorable for the agriculture of considered regions.

\section{Conclusion}

The impacts of the reforestation on the intraseasonal variability of precipitation as well as on the spatial distribution of extreme precipitation events were quantified over West Africa during the summer period (June to September from 2003 to 2009) using two versions of the ICTP regional climate model RegCM4: the standard version and the modified one of the same model taking into account a zonal band of reforested area at the Sahel-Sahara interface. These two versions of the model were used at the same horizontal resolution of $50 \mathrm{~km}$ and forced by ERA-Interim reanalysis. The validation step shows that the RegCM4 model can well simulate West African summer rainfall. The reforestation significantly modifies the rainfall signal over West Africa by increasing it over the reforested zone and outside this zone with strong values localized over the Fouta Jallon highlands. At the intraseasonal timescale, the reforestation also tends to increase rainfall globally between $3^{\circ} \mathrm{N}$ and $20^{\circ} \mathrm{N}$ with a maximum during the monsoon onset period (from May to June) around $4^{\circ} \mathrm{N}$. The reforestation affects rainfall locally but also over remote regions as found in previous studies [49]. Surface temperature was also impacted by this land cover change. A decrease of temperature is noted over the Sahel and the reforested zone during the summer period.

This decrease is stronger (more than $-3^{\circ} \mathrm{C}$ ) between the latitudes $12^{\circ} \mathrm{N}$ and $15^{\circ} \mathrm{N}$; this is consistent with the observed rainfall and moisture increase simulated over that region. Moreover, this work provides a first overview of the impacts of the reforestation at the Sahel-Sahara interface on West African monsoon onset and extreme precipitation events. The results indicate that the two runs simulate very well the spatial distribution of the extreme precipitation events. The reforestation induces the following results:

(i) An increase of the number of rainy days $(R>1 \mathrm{~mm})$ over the reforested area and the Sahel region.

(ii) An increase of the frequency of the intense rainfall events ( $R \geq 10 \mathrm{~mm} /$ day) over orographic regions and the Sahel including the southern part of the reforested zone.

(iii) An increase of the very intense rainfall events $(R \geq$ $20 \mathrm{~mm} /$ day) off the Fouta Jallon highlands.

(iv) An increase of the maximum cumulative pentad (RX5day) over the southern part of the reforested zone, the western Sahel, and orographic regions such as the Fouta Jallon and the ocean (around $7^{\circ} \mathrm{N}$ ).

(v) An increase of the mean 90th percentile over Senegal and off the Fouta Jallon highlands. (vi) An increase of the mean 95th and 99th percentile over the reforested zone and the oceanic region.

(vii) An increase of the consecutive wet days (CWD) over and off Fouta Jallon highlands and a decrease of the dry spells events (CDD) over the northern Sahel and the reforested zone.

These results show that the reforestation affects mainly strong rainfall events as well as the maximum duration of the CDD and CWD suggesting that this vegetation cover change may have a positive impact on Sahelian countries agriculture. However the increase of strong rainfall events may induce dramatic consequences such as flooding. Despite the results obtained in this work, additional works are needed to better explain the impacts of the reforestation on the spatial distribution of the extreme precipitation events over West Africa for the present day but also for the future using climate change scenarios because these hydroclimatic intense events remain a major concern for West African countries which are known to have a low adaptation capacity.

\section{Competing Interests}

The authors declare that they have no competing interests.

\section{Acknowledgments}

The authors are grateful to the Assane SECK University of Ziguinchor (Senegal) for its support.

\section{References}

[1] J. Lu and T. L. Delworth, "Oceanic forcing of the late 20th century Sahel drought," Geophysical Research Letters, vol. 32, no. 22, 2005.

[2] F. Giorgi, E. Coppola, F. Raffaele et al., "Changes in extremes and hydroclimatic regimes in the CREMA ensemble projections," Climatic Change, vol. 125, no. 1, pp. 39-51, 2014.

[3] I. Diallo, F. Giorgi, A. Deme, M. Tall, L. Mariotti, and A. T. Gaye, "Projected changes of summer monsoon extremes and hydroclimatic regimes over West Africa for the twenty-first century," Climate Dynamics, 2016.

[4] L. Le Barbé, T. Lebel, and D. Tapsoba, "Rainfall variability in West Africa during the years 1950-90," Journal of Climate, vol. 15, no. 2, pp. 187-202, 2002.

[5] P. J. Lamb and R. A. Peppler, "Further case studies of tropical Atlantic surface atmospheric and oceanic patterns associated with sub-Saharan drought," Journal of Climate, vol. 5, no. 5, pp. 476-488, 1992.

[6] S. E. Nicholson, "Land surface processes and Sahel climate," Reviews of Geophysics, vol. 38, no. 1, pp. 117-139, 2000.

[7] A. Dai, P. J. Lamb, K. E. Trenberth, M. Hulme, P. D. Jones, and P. Xie, "The recent Sahel drought is real," International Journal of Climatology, vol. 24, no. 11, pp. 1323-1331, 2004.

[8] C. K. Folland, T. N. Palmer, and D. E. Parker, "Sahel rainfall and worldwide sea temperatures, 1901-1985," Nature, vol. 320, pp. 602-607, 1986.

[9] S. Hastenrath and P. Lamb, "Some aspects of circulation and climate over the eastern equatorial atlantic," Monthly Weather Review, vol. 105, no. 8, pp. 1019-1023, 1977. 
[10] S. M. Hagos and K. H. Cook, "Ocean warming and latetwentieth-century Sahel drought and recovery," Journal of Climate, vol. 21, no. 15, pp. 3797-3814, 2008.

[11] G. S. Jenkins, A. T. Gaye, and B. Sylla, "Late 20th century attribution of drying trends in the Sahel from the Regional Climate Model (RegCM3)," Geophysical Research Letters, vol. 32, no. 22, Article ID L22705, 2005.

[12] S. E. Nicholson, "The intensity, location and structure of the tropical rainbelt over west Africa as factors in interannual variability," International Journal of Climatology, vol. 28, no. 13, pp. 1775-1785, 2008.

[13] J. G. Charney, "Dynamics of deserts and drought in the Sahel," Quarterly Journal of the Royal Meteorological Society, vol. 101, no. 428, pp. 193-202, 1975.

[14] F. H. M. Semazzi and L. Sun, "The role of orography in determining the Sahelian climate," International Journal of Climatology, vol. 17, no. 6, pp. 581-596, 1997.

[15] A. Konaré, A. S. Zakey, F. Solmon et al., "A regional climate modeling study of the effect of desert dust on the West African monsoon," Journal of Geophysical Research: Atmospheres, vol. 113, no. 12, Article ID D12206, 2008.

[16] M. Camara, G. Jenkins, and A. Konare, "Impacts of dust on West African climate during 2005 and 2006," Atmospheric Chemistry and Physics Discussions, vol. 10, no. 2, pp. 3053-3086, 2010.

[17] H. Paeth and A. Hense, "SST versus climate change signals in West African rainfall: 20th-century variations and future projections," Climatic Change, vol. 65, no. 1-2, pp. 179-208, 2004.

[18] I. M. Held, T. L. Delworth, J. Lu, K. L. Findell, and T. R. Knutson, "Simulation of Sahel drought in the 20th and 21st centuries," Proceedings of the National Academy of Sciences of the United States of America, vol. 102, no. 50, pp. 17891-17896, 2005.

[19] J. P. Grist, S. E. Nicholson, and A. I. Barcilon, "Easterly waves over Africa. Part II: observed and modeled contrasts between wet and dry years," Monthly Weather Review, vol. 130, no. 2, pp. 212-225, 2002.

[20] A. Ali, "Climate variability and change in the Sahel. Understanding the current situation by observing Climate change in the Sahel. A challenge for sustainable development," in AGRHYMET Monthly Bulletin (Special Issue), pp. 17-20, 2011, http://www.agrhymet.ne/PDF/pdfeng/specialChCang.pdf.

[21] X. Y. Zheng and E. A. B. Eltahir, "The role of vegetation in the dynamics of West African monsoons," Journal of Climate, vol. 11, no. 8, pp. 2078-2096, 1998.

[22] B. J. Abiodun, J. S. Pal, E. A. Afiesimama, W. J. Gutowski, and A. Adedoyin, "Simulation of West African monsoon using RegCM3 Part II: impacts of deforestation and desertification," Theoretical and Applied Climatology, vol. 93, no. 3-4, pp. 245261, 2008.

[23] Y. Xue, H.-M. H. Juang, W.-P. Li et al., "Role of land surface processes in monsoon development: East Asia and West Africa," Journal of Geophysical Research D: Atmospheres, vol. 109, no. 3, Article ID D03105, 2004.

[24] T. B. Love, V. Kumar, P. P. Xie, and W. Thiaw, "A 20-year daily Africa precipitation climatology using satellite and gauge data," in Proceedings of the 14th Conference on Applied Climatology, $\mathrm{p}$. 5, American Meteorological Society, 2004.

[25] A. Ali, A. Amani, A. Diedhiou, and T. Lebel, "Rainfall estimation in the Sahel-part II: evaluation of rain gauge networks in the CILSS countries and objective intercomparison of rainfall products," Journal of Applied Meteorology, vol. 44, no. 11, pp. 1707-1722, 2005.
[26] M. Camara, A. Diedhiou, B. A. Sow et al., "Analyse de la pluie simulée par les modèles climatiques régionaux de CORDEX en Afrique de l'Ouest," Sécheresse, vol. 24, no. 1, pp. 14-28, 2013.

[27] L. Mouhamed, S. B. Traore, A. Alhassane, and B. Sarr, "Evolution of some observed climate extremes in the West African Sahel," Weather and Climate Extremes, vol. 1, pp. 19-25, 2013.

[28] M. B. Sylla, F. Giorgi, E. Coppola, and L. Mariotti, "Uncertainties in daily rainfall over Africa: assessment of gridded observation products and evaluation of a regional climate model simulation," International Journal of Climatology, vol. 33, no. 7, pp. 1805-1817, 2013.

[29] N. A. B. Klutse, M. B. Sylla, I. Diallo et al., "Daily characteristics of West African summer monsoon precipitation in CORDEX simulations," Theoretical and Applied Climatology, vol. 123, no. 1-2, pp. 369-386, 2016.

[30] I. Diallo, M. B. Sylla, M. Camara, and A. T. Gaye, "Interannual variability of rainfall over the Sahel based on multiple regional climate models simulations," Theoretical and Applied Climatology, vol. 113, no. 1-2, pp. 351-362, 2013.

[31] F. Giorgi, E. Coppola, F. Solmon et al., "RegCM4: model description and preliminary tests over multiple CORDEX domains," Climate Research, vol. 52, no. 1, pp. 7-29, 2012.

[32] R. E. Dickinson, S. A. Henderson, and P. J. Kennedy, "BiosphereAtmosphere Transfer Scheme (BATS) version 1E as coupled to the NCAR Community Climate Model," Tech. Rep. NCAR TN387+STR, 1993.

[33] A. A. M. Holtslag, E. I. F. De Bruijn, and H.-L. Pan, "A high resolution air mass transformation model for short-range weather forecasting," Monthly Weather Review, vol. 118, no. 8, pp. 1561-1575, 1990.

[34] J. S. Pal, E. E. Small, and E. A. B. Eltahir, "Simulation of regionalscale water and energy budgets: representation of subgrid cloud and precipitation processes within RegCM," Journal of Geophysical Research Atmospheres, vol. 105, no. 24, pp. 2957929594, 2000.

[35] G. A. Grell, "Prognostic evaluation of assumptions used by cumulus parameterizations," Monthly Weather Review, vol. 121, no. 3, pp. 764-787, 1993.

[36] J. M. Fritsch and C. F. Chappell, "Numerical prediction of convectively driven mesoscale pressure systems. Part I: convective parameterization," Journal of the Atmospheric Sciences, vol. 37, no. 8, pp. 1722-1733, 1980.

[37] K. A. Emanuel, "A scheme for representing cumulus convection in large-scale models," Journal of the Atmospheric Sciences, vol. 48, no. 21, pp. 2313-2335, 1991.

[38] T. C. Peterson, C. Folland, G. Gruza, W. Hogg, A. Mokssit, and N. Plummer, "Report on the activities of the working group on climate change detection and related rapporteurs 1998-2001," WMO Rep. WCDMP 47, WMO-TD 1071, 2001.

[39] R. F. Adler, G. J. Huffman, A. Chang et al., "The version-2 global precipitation climatology project (GPCP) monthly precipitation analysis (1979-present)," Journal of Hydrometeorology, vol. 4, no. 6, pp. 1147-1167, 2003.

[40] G. Nikulin, C. Jones, F. Giorgi et al., "Precipitation climatology in an ensemble of CORDEX-Africa regional climate simulations," Journal of Climate, vol. 25, no. 18, pp. 6057-6078, 2012.

[41] I. Jobard, F. Chopin, J. C. Berges, and R. Roca, "An intercomparison of 10-day satellite precipitation products during West African monsoon," International Journal of Remote Sensing, vol. 32, no. 9, pp. 2353-2376, 2011. 
[42] A. S. Simmons, D. Uppala, and S. Kobayashi, "ERA-interim: new ECMWF reanalysis products from 1989 onwards," ECMWF Newsletter, vol. 110, pp. 29-35, 2007.

[43] S. Uppala, D. Dee, S. Kobayashi, P. Berrisford, and A. Simmons, "Towards a climate data assimilation system: status update of ERA-Interim," ECMWF Newsletter, vol. 115, pp. 12-18, 2008.

[44] S. Kothe and B. Ahrens, "On the radiation budget in regional climate simulations for West Africa," Journal of Geophysical Research Atmospheres, vol. 115, no. D23, 2010.

[45] P. Oettli, B. Sultan, C. Baron, and M. Vrac, "Are regional climate models relevant for crop yield prediction in West Africa?" Environmental Research Letters, vol. 6, no. 1, Article ID 014008, 2011.

[46] H. Paeth, N. M. J. Hall, M. A. Gaertner et al., "Progress in regional downscaling of west African precipitation," Atmospheric Science Letters, vol. 12, no. 1, pp. 75-82, 2011.

[47] D. P. Dee, S. M. Uppala, A. J. Simmons et al., "The ERAInterim reanalysis: configuration and performance of the data assimilation system," Quarterly Journal of the Royal Meteorology Society, vol. 137, no. 656, pp. 553-597, 2011.

[48] I. Diallo, C. L. Bain, A. T. Gaye et al., "Simulation of the West African monsoon onset using the HadGEM3-RA regional climate model," Climate Dynamics, vol. 43, no. 3-4, pp. 575-594, 2014.

[49] B. J. Abiodun, Z. D. Adeyewa, P. G. Oguntunde, A. T. Salami, and V. O. Ajayi, "Modeling the impacts of reforestation on future climate in West Africa," Theoretical and Applied Climatology, vol. 110, no. 1-2, pp. 77-96, 2012.

[50] B. Sultan and S. Janicot, "The West African monsoon dynamics-part II: the 'preonset' and 'onset' of the summer monsoon," Journal of Climate, vol. 16, no. 21, pp. 3407-3427, 2003. 

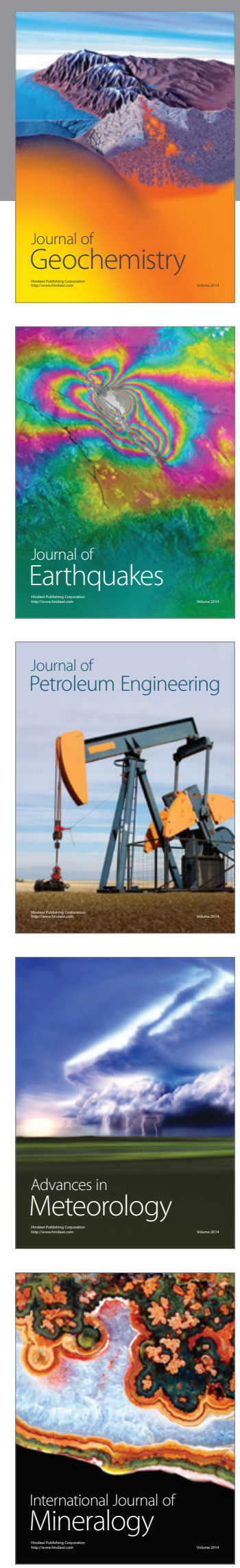
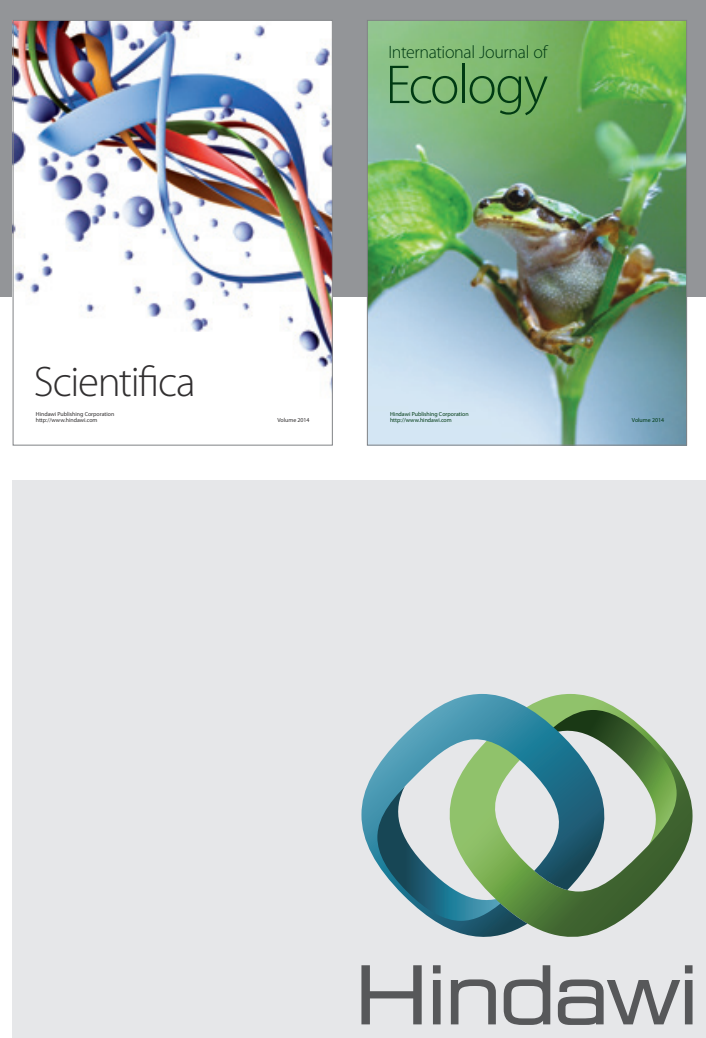

Submit your manuscripts at

http://www.hindawi.com
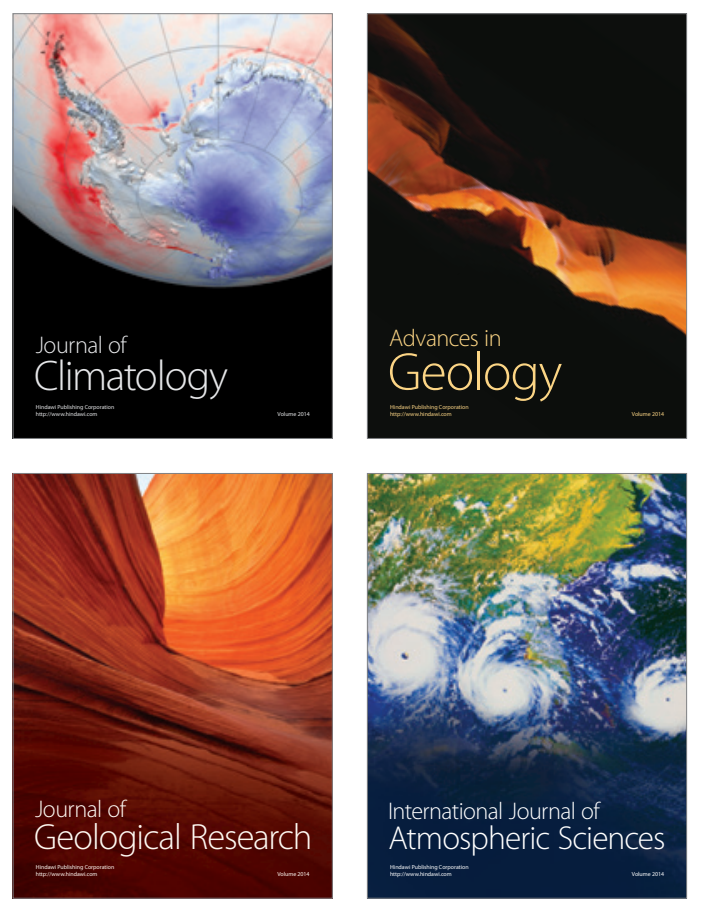

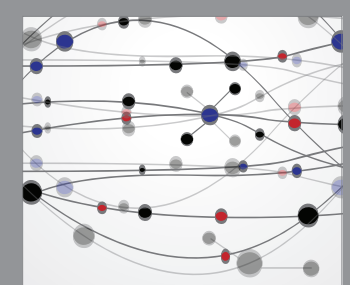

The Scientific

\section{World Journal}
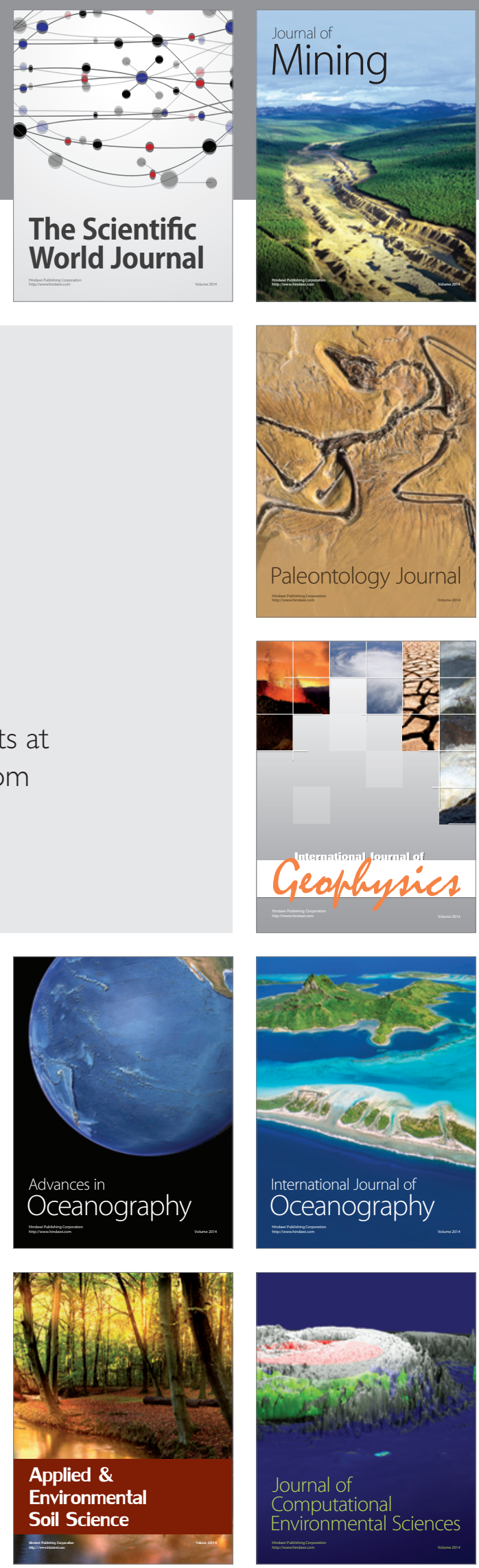